\title{
Low winter precipitation, but not warm autumns and springs, threatens mountain butterflies in middle-high mountains
}

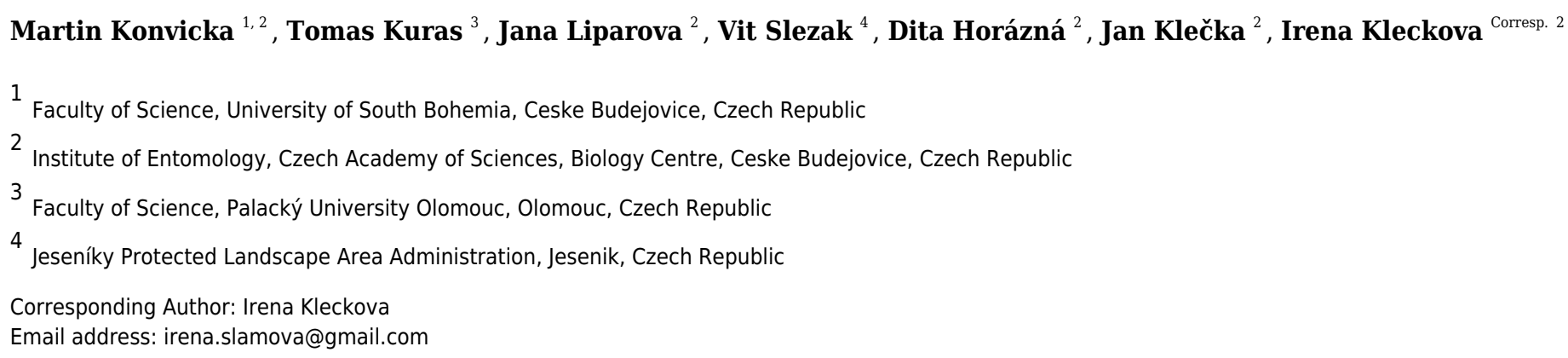

Low-elevation mountains represent unique model systems to study species endangered by climate warming, such as subalpine and alpine species of butterflies. We aimed to test the effect of climate variables experienced by Erebia butterflies during their development on adult abundances and phenology, targeting the key climate factors determining the population dynamics of mountain insects. We analysed data from a long-term monitoring of adults of two subalpine and alpine butterfly species, Erebia epiphron and E. sudetica (Nymphalidae: Satyrinae) in the Jeseník Mts and Krkonoše Mts (Czech Republic). Our data revealed consistent patterns in their responses to climatic conditions. Lower precipitation (i.e., less snow cover) experienced by overwintering larvae decreases subsequent adult abundances. Conversely, warmer autumns and warmer and drier springs during the active larval phase increase adult abundances and lead to earlier onset and extended duration of the flight season. The population trends of these mountain butterflies are stable or even increasing. On the background of generally increasing temperatures within the mountain ranges, population stability indicates dynamic equilibrium of positive and detrimental consequences of climate warming among different life history stages. These contradictory effects warn against simplistic predictions of climate change consequences on mountain species based only on predicted increases in average temperature. Microclimate variability may facilitate the survival of mountain insect populations, however the availability of suitable habitats will strongly depend on the management of mountain grasslands. 


\section{Low winter precipitation, but not warm autumns and springs,}

\section{2 threatens mountain butterflies in middle-high mountains}

5 Martin Konvicka ${ }^{1,2}$, Tomas Kuras ${ }^{3}$, Jana Liparova ${ }^{2}$, Vit Slezak ${ }^{4}$, Dita Horazna ${ }^{2}$, Jan

$6 \mathrm{Klecka}^{2}$, Irena Kleckova ${ }^{2 *}$

$9{ }^{1}$ Faculty of Science, University of South Bohemia, Branišovská 31, CZ-37005 České

10 Budějovice, Czech Republic

$11{ }^{2}$ Czech Academy of Sciences, Biology Centre, Institute of Entomology, Branišovská 31, CZ-

1237005 České Budějovice, Czech Republic

$13{ }^{3}$ Faculty of Science, Palacký University Olomouc, 17. listopadu 1192/12, CZ-77146 Olomouc,

14 Czech Republic

15 4Jeseníky Protected Landscape Area Administration, Šumperská 93, CZ-79001 Jeseník, Czech

16 Republic

17 


\section{Abstract}

22
Low-elevation mountains represent unique model systems to study species endangered by climate warming, such as subalpine and alpine species of butterflies. We aimed to test the effect of climate variables experienced by Erebia butterflies during their development on adult abundances and phenology, targeting the key climate factors determining the population dynamics of mountain insects. We analysed data from a long-term monitoring of adults of two subalpine and alpine butterfly species, Erebia epiphron and E. sudetica (Nymphalidae: Satyrinae) in the Jeseník Mts and Krkonoše Mts (Czech Republic). Our data revealed consistent patterns in their responses to climatic conditions. Lower precipitation (i.e., less snow cover) experienced by overwintering larvae decreases subsequent adult abundances. Conversely, warmer autumns and warmer and drier springs during the active larval phase increase adult abundances and lead to earlier onset and extended duration of the flight season. The population trends of these mountain butterflies are stable or even increasing. On the background of generally increasing temperatures within the mountain ranges, population stability indicates dynamic equilibrium of positive and detrimental consequences of climate warming among different life history stages. These contradictory effects warn against simplistic predictions of climate change consequences on mountain species based only on predicted increases in average temperature. Microclimate variability may facilitate the survival of mountain insect populations, however the availability of suitable habitats will strongly depend on the management of mountain grasslands. 


\section{Keywords}

47 alpine environments, butterfly monitoring, climate change, phenology, snow, winter

\section{Introduction}

53 One of the conservation concerns with the currently warming climate is the fate of alpine-zone

54 species inhabiting "middle-high mountains", which only slightly overtop the timberline (Boggs

55 \& Murphy, 1997; Schmitt et al., 2014). Whereas space allows the alpine species upslope

56 distribution shifts in high mountain ranges (Pauli et al., 2012), species inhabiting lower

57 mountains may become trapped at their current locations (Freeman et al., 2018; Schmitt et al.,

58 2005), e.g., by ascending timberline (Roland \& Matter, 2007). It is desirable to closely monitor

59 such systems, to analyse their responses to changing climate, and to design, if necessary, rescue

60 measures, which may include management of habitats (Garcia-Gonzalez, 2008) or translocations

61 (Schmitt et al., 2005).

With over 100 species across the Holarctic realm and 40 species in Europe (Tennet,

63 2008), the butterfly genus Erebia Dalman, 1816 (Nymphalidae, Satyrinae) represents a clade

64 with many of its species adapted to cold conditions. It originated in Central Asia during the

65 Miocene (Pena et al., 2015) and radiated into rising mountains (Hinojosa et al., 2018). All

66 constituent species develop on grasses, overwinter as larvae, and either form a single annual

67 brood, or prolong their development across multiple seasons (Sonderegger, 2005). They display

68 remarkable diversity in larval cold hardiness (Vrba et al., 2017a) and adult thermoregulation 
69 (Kleckova et al., 2014), resulting in a diversity of micro-habitat use (Sonderegger, 2005) and

70 diverse species assemblages in high mountains (Grill et al., 2020; Polic et al. 2014). Lower-

71 altitude mountains host lower Erebia diversity but allow exploring the effects of climatic

72 variability on sub-alpine butterflies on the margins of their climatic tolerances. Earlier studies

73 revealed upslope distribution shifts (Franco et al., 2006; Scalercio et al., 2014) and advancing

74 adult flight (Konvicka et al. 2016) attributable to the currently warming climate.

75 Climate, in particular temperature, affects insect thermoregulation (Eller \& Boggs, 2004;

76 Turlure et al., 2010), overwintering mortality (Vrba et al., 2014), and adult activity (Buckley \&

77 Kingsolver, 2012). It influences food intake (Forrest \& Thomson, 2011), development rate

78 (Ayers \& Scriber, 1994), and pressure from natural enemies (Corcos et al., 2018). All these

79 factors ultimately affect adult abundance (Roland et al., 2020) and flight period timing

80 (Gutiérrez \& Willson, 2020).

81 Adult abundance affects populations' survival across years (McLaughlin et al., 2002),

82 dispersal across habitats (Hanski 1999), and adaptation to changing conditions (Watt et al.,

83 2003). The links between phenology and population fitness are more intricate (Davies et al.,

84 2019). For mountain species restricted to narrow time windows with suitable conditions,

85 advanced adult flight period prolongs the time available for mating and oviposition (Stewart et

86 al., 2019). The physiological triggers speeding-up development may be intuitive, such as warm

87 springs (Gutiérrez \& Willson, 2020; Stewart et al. 2019), or less straightforward, and may

88 include warm periods in autumn (Pak et al., 2019) or deep winter frosts (Stalhandske et al.,

89 2017). On the other hand, too warm temperatures during larval periods may impair energy

90 assimilation (Klockmann et al., 2018) and even increase mortality (Karl et al. 2011), and adult

91 mortality may increase due to heat shocks (Janowitz \& Fischer, 2011). 
Here, we analyse the effects of climate variability on adult abundance and phenology of

93 two Erebia species inhabiting two middle-high massifs of the Sudeten mountains, Czech

94 Republic, Central Europe: the Hrubý Jeseník Mts and Krkonoše Mts. The treeline within these

95 mountain ranges is situated at higher temperatures than the global treeline isotherm (Kuzelova \&

96 Treml, 2020) so that the low-elevation alpine habitats would be overgrown by forest, if following

97 the thermal isoclines only. This can be caused by winds (cf. Kaspar et al., 2017), a time-lag of

98 tree growth response to abrupt climate change, or past pastoralism (Kuzelova \& Treml, 2020).

99 These mountains have recently experienced rising temperatures (Migala et al., 2016), whereas

100 precipitation is highly fluctuating, without a long-term trend (Twardosz \& Cebulska, 2020). The

101 studied butterflies Erebia epiphron (Knoch, 1783) and E. sudetica (Staudinger, 1861) are similar

102 morphologically, but use different habitats. The former inhabits wind-exposed summit plateaus,

103 whereas the latter occupies wind-shielded valley slopes (Kuras et al., 2003). Both species occur

104 naturally in the Jeseník Mts, whereas the Krkonoše Mts host a non-native E. epiphron

105 population, established there since the 1930s (Schmitt et al., 2005).

106 Owing to restriction of the species to the narrow sub-alpine/alpine zone, population

107 trends cannot be masked by immigration from lower elevations ( $c f$. Gutiérrez \& Wilson, 2020).

108 The conditions experienced by earlier developmental stages determine abundance of subsequent

109 phases (Radchuk et al., 2013; Roland \& Matter, 2016). Thus, we tested the effect of climatic

110 conditions experienced by larvae during the autumn, winter and spring on subsequent adult

111 abundances. Erebia females are in flight and oviposit during August. Hatched larvae feed on

112 grasses during September and October. Then, the larvae overwinter until May and start to

113 activate again in June. It is difficult to quantify the direct effect of climate on larval survival (cf.

114 Rytteri, 2021). In our study, we defined two periods of larval activity (autumn and spring) and 
115 the overwintering period. Then, we analysed the effect of climatic conditions during these

116 developmental phases on subsequent adult abundances based on long-term adult monitoring data.

117 . We tested which climate variables experienced by Erebia butterflies during their

118 development influence their adult abundances and phenology, targeting the key climate factors

119 determining the population dynamics of mountain specialist insects.

120

121

122 Materials and methods

123

124 Study area and species

125 Both the Jeseník Mts (highest summit: Praděd, 1491m, N 504.96', E 17¹3.85', hereinafter “J”)

126 and Krkonoše Mts (Sněžka, 1603 m, N 5044.16', E 1544.38'E, hereinafter 'K”) were formed

127 by Variscan orogeny and consist of rolling ridges built from metamorphic $(\mathrm{J}, \mathrm{K})$ and crystallinite

128 (K) rocks. The timberline, situated at ca $1300 \mathrm{~m}$, is formed by sparse Picea abies growths,

129 replaced upslope by Pinus mugo shrubs (the latter non-native in J: Kasak et al., 2015). The

130 summit elevations are covered by species-poor grasslands and heaths, dominated by Nardus

131 stricta, Avenella flexuosa, Vaccinium myrtillus, and Calluna vulgaris $\left(\approx 10 \mathrm{~km}^{2}\right.$ in $\mathrm{J}, \approx 50 \mathrm{~km}^{2}$ in

$132 \mathrm{~K})$. Much richer and structurally diverse vegetation is found at valley headwalls near the

133 timberline (Fig. 1). The (sub)alpine fauna of the mountains is impoverished due to isolation from

134 other massifs overtopping the timberline (aerial distance $\mathrm{J}-\mathrm{K}: 130 \mathrm{~km}$; J - Mala Fatra Mts,

135 Carpathians: 160 km; J - Schneeberg Mt, Eastern Alps: 270 km).

136 Erebia sudetica occurs in several mountain systems outside of the Alps: Mons du Cantal,

137 France; the Carpathians (Rodna Mts, Retezat Mts, Godeanu-Tarcu Mts, Ciuicas Mts, Fagaras 
138 Mts, Cuvelier \& Dinca 2007) ; Jeseníky Mts, the Czech Republic. It occurs in two Western Alps

139 districts (E. Isére, France; the Bernese Alps, Switzerland). In terms of taxonomy, it appears

140 paraphyletic with E. melampus (Fuessly, 1775) (Haubrich \& Schmitt, 2007; Pena et al., 2015)

141 and J represents the northernmost and highly isolated locality of the melampus/sudetica species

142 complex. In J, it forms spatially restricted colonies at subalpine tall-herb formations, plus at

143 lower-elevated woodland openings (Konvicka et al., 2014).

Erebia epiphron is the most widely distributed European alpine Erebia. Besides J and

$145 \mathrm{~K}$, it inhabits the mountains of Scotland and northern England, Cantabrian Mts in Spain, the Harz

146 Mts in Germany (extinct), the Pyrenees, Massif Central and Vosges in France, Central

147 Apennines in Italy, Alps,Carpathians, and the Dinaric mountains of the Balkans southward to

148 northernmost Greece (Hinojosa et al., 2018, see Minter et al. 2020). The populations of

149 particular mountain regions are genetically unique (Minter et al. 2020). Across this range, it

150 prefers Nardus dominated grasslands on nutrient-poor bedrock (Ewing et al., 2020). It is

151 restricted to elevations above the timberline in J (Kuras et al., 2003), whereas its non-native $\mathrm{K}$

152 population has also colonised cultural grasslands down to $\approx 1100 \mathrm{~m}$ (Cizek et al., 2015).

153

Both species are in flight in July - August. During warm years, the adults emerge at

154 the end of June. Larvae are oligophagous on grasses (Sonderegger, 2005). They feed during

155 September and October, overwinter in grass tussock, and resume feeding after the snow melt in

156 mid-May. Biennial development occurs in E. epiphron in the Alps (Sonderegger, 2005), whereas

157 univoltine development was observed in E. melampus (Wipking \& Mengelkoch, 1994), closely

158 related to E. sudetica. In our study system, we assume that univoltine development prevails also

159 in E. epiphron, as the species does not display biennial adult abundance fluctuations in J 
160 (Konvicka et al., 2016) and both species developed with a single overwintering in a rearing

161 experiment (Kuras et al., 2001).

162

163 Adult numbers monitoring

164 The study is based on transect monitoring of relative abundance of adult butterflies (2009-2020,

165 plus an earlier 5-year period 1995-1999 for one of the transects), combined with meteorological

166 data from nearby weather stations. This time span is sufficient to detect butterfly population

167 trends and to test the effects of climate variability on adult abundance changes (see Wilson \&

168 Fox, 2020). We established three transects in J (J1-J3, total length $4.2 \mathrm{~km}$, altitude $1325-1492 \mathrm{~m}$

169 a.s.1.) and four in $\mathrm{K}(\mathrm{K} 1-\mathrm{K} 4$, total length $7.1 \mathrm{~km}$, altitude $1120-1510 \mathrm{~m}$ a.s.1.) (Fig. 1 and

170 Supporting Information, Supplementary methods).

171 We monitored both species in $\mathrm{J}$ in 2009-2020 (12 years), plus E. epiphron, J1 only, in

172 1995-1999 (5 years). In K, E. epiphron was monitored in 2010-2020 (11 years) (Supporting

173 Information, Table S1). The transects were walked 2-4 times per week, weather permitting,

174 between 1 July and 15 August, except for 2009, when the monitoring terminated earlier, and the

175 extraordinarily warm year 2018, with the first random records from June 7. Monitoring started

176 earlier (15 June) during 2019 and 2020 to cover the possibility of an earlier emergence of adults.

177 However, we did not record any adults before the beginning of July during these two years with

178 extended monitoring period. The walks were restricted to air temperature $>15^{\circ} \mathrm{C}$, clear or half-

179 overcast sky, and wind $<11 \mathrm{~km} / \mathrm{h}$. Permissions for the field research were obtained from the

180 administration of the Jeseníky Protected Landscape Area (permit no. 442/JS/10) and the

181 administration of the Krkonoše National Park (permit no. KRNAP 03599/2013).

182 


\section{Abundance and phenology indices}

184 We described the relative annual abundance using the population abundance index (PAI)

185 (Kleckova et al., 2015; Konvicka et al., 2016), a measure derived from the shapes of the

186 population recruitment curves, defined by daily relative abundances related to day-of-year

187 (Rothery \& Roy, 2001) (Supporting Information, Table S1). We fitted the curves (Supporting

188 Information, Figs. S1-S11) via the generalised additive models (GAMs) using mgcv (Wood,

189 2011) in $\mathrm{R}$ 3.4.4 ( $\mathrm{R}$ Core Team, 2018), with cubic splines $(\mathrm{k}=4)$ and quasi-Poisson errors. The

190 number of daily records were standardised for unit transect length. To facilitate the convergence

191 of the fitted curve to zero prior to and after the adult flight period, zero values were added one

192 week before the first monitoring record and two weeks after the last adults observation on the

193 transect. The areas under the GAM curves were computed using the rectangle method, which

194 approximates a definite integral. Specifically, the date interval between the added zeroes for each

195 species and transect was divided into subintervals of length 0.01 days $(x)$, predicted abundance

196 value (y) was generated for each subinterval by the relevant GAM, and the areas of the resulting

197 rectangles $(x * y)$ were summed across the entire date interval to obtain the approximate area

198 under the curve, i.e. the population abundance index $(P A I)$.

199 For phenology, we used the GAM-fitted population recruitment curves (Supporting

200 Information, Figs. S1-S11) and the function predict (library mgcv) to infer the days when $20 \%$

201 and $80 \%$ of individuals were in flight (an example script is available in Figshare at

202 https://doi.org/10.6084/m9.figshare.14642472). The 20\% day is herein the flight period onset,

203 and $20 \%-80 \%$ day interval length is the flight period duration (Supporting Information, Table

204 S1). This diminishes the uncertainty which would arise from using the dates of the first and last

205 observed individual to describe the flight period duration. 


\section{Climate variables}

208 Monthly weather data were provided by the Czech Hydrometeorological Institute

209 (https://www.chmi.cz/historicka-data/pocasi/mesicni-data). For J, 1995-1997 records were from

210 the Mt Praděd meteorological station (1491m, N 50.0831 ${ }^{\circ}$ E $\left.17.2310^{\circ}\right)$ adjoining the transect $\mathrm{J}$,

211 and 2009-2020 records from Mt Šerák station (1328 m, N 50.1874 E $\left.17.1082^{\circ}\right)$, located $15 \mathrm{~km}$

212 NW, but climatically equivalent to the study sites. For K (2010-2020), we used records from the

213 Luční Bouda station (1410 m, N 50.7344 E $\left.15.6973^{\circ}\right)$ for the summit transects K3 and K4, and

214 from the Pec pod Sněžkou station $\left(820 \mathrm{~m}, \mathrm{~N} 50.6918^{\circ} \mathrm{E} 15.7287^{\circ}\right)$ for the lower-altitude

215 transects K1 and K2.

216 Adult abundance and phenology may be affected by weather experienced by the

217 immatures (Turlure et al., 2010), including extremes such as ground frosts. For the pre-

218 hibernation larvae (September-October), we considered total autumn precipitation $\left(P_{t o t} A u t\right)$, as

219 well as monthly average $\left(T_{\text {avg }} A u t\right)$, maximum $\left(T_{\max } A u t\right)$, minimum $\left(T_{\min } A u t\right)$, and ground

220 minimum $\left(T_{\text {ground }} A u t\right)$ temperatures, averaged across the two months (Supporting Information,

221 Table S1). For the overwintering (November-April), when the mountains are usually snow-

222 covered, we used the variables as above (indexed $P_{\text {tot }}$ Win, $T_{\text {avg }}$ Win, $T_{\max }$ Win,$T_{\min }$ Win, $T_{\text {ground }}$ Win)

223 and the snow cover duration (in days, $S n o w_{\text {days }}$ ). For the spring larval period (May-June), we

224 used the same predictors as for autumn (indexed $P_{\text {tot }} S p r, T_{a v g} S p r, T_{\max } S p r, T_{\min } S p r, T_{\text {ground }} S p r$ ).

225 The same applied for summer (July-August), when the weather directly affects the adults

226 ( $P_{\text {tot }}$ Sum, $T_{\text {avg }}$ Sum, $T_{\max }$ Sum, $T_{\text {min }}$ Sum, $T_{\text {ground }}$ Sum $)$.

Whereas most of the climate variables were available for all years in J (1995-1997+

228 2009-2020, herein $\left.\mathrm{J}_{\text {all }}\right)$ the monthly number of snow days $\left(\right.$ Snow $\left._{\text {days }}\right)$ and ground minimum 
229 temperature $\left(T_{\text {ground }}\right)$ were available only for the $\mathrm{J}$ recent period (2009-2020), $\mathrm{J}_{\text {rec }}$. The ground

230 minimum temperature, measured at $5 \mathrm{~cm}$ above the ground, provides a proxy for days with

231 ground frost, possibly critical for larval survival (Vrba et al., 2012). $T_{\text {ground }}$ and Snow days were not

232 available for $\mathrm{K}$.

233 We calculated the Pearson's correlation coefficients for all climate variables for $\mathrm{J}_{\text {all }}$,

$234 \mathrm{~J}_{\mathrm{rec}}, \mathrm{K}$ lower altitudes (transects $\left.\mathrm{K} 1, \mathrm{~K} 2\right)$, and $\mathrm{K}$ higher altitudes $(\mathrm{K} 3, \mathrm{~K} 4)$, and visualised the

235 matrices using the package corrplot (Dray, 2008) (Supporting Information, Figs. S12-S15). We

236 also computed the Principal Component Analysis (PCA) in vegan for R (Oksanen et al., 2019)

237 (Supporting Information, Fig. S16). These analyses revealed multiple correlations among the

238 climate variables, but without a clear general pattern.

\section{Statistical analyses}

241 We conducted a separate analysis for each mountain range and for the two periods in $\mathrm{J}: \mathrm{J}_{\text {all }}$ and

$242 \mathrm{~J}_{\mathrm{rec}}$. We ran the analyses separately for the two species in $\mathrm{J}_{\mathrm{rec}}$. We first tested whether there was a

243 temporal trend in the abundance and phenology of the butterflies, and in the climate variables.

244 We used generalised linear models (GLM) in R to test the linear effect of year on the response

245 variables, with transect identity as a fixed effect. We also tested for possible biennial abundance

246 fluctuations in population abundance index of E. sudetica and E. epiphron using a GLM with

247 odd $v s$ even year as a predictor, including the transect identity and linear effect of the year as

248 covariates. We similarly tested whether PAI depended on Onset and Duration, and whether the

249 two phenological variables were correlated.

250 For the effect of climate predictors on PAI, Onset and Duration, we tested the effects of

251 conditions experienced by autumn, overwintering, and spring larvae, and the effect of conditions 
252 experienced by adults during their flight period on $P A I$ and Duration. Separate analyses were

253 performed for four datasets: E. sudetica, E. epiphron $\mathrm{K}$, E. epiphron $\mathrm{J}_{\mathrm{rec}}$, and E. epiphron $\mathrm{J}_{\mathrm{all}}$ to

254 account for differences in the availability of climate variables between $\mathrm{J}$ and $\mathrm{K}$, and between $\mathrm{J}_{\text {rec }}$

255 and $\mathrm{J}_{\text {all }}$. Analysing E. epiphron data separately for $\mathrm{J}$ and $\mathrm{K}$ allowed detection of possible inter-

256 population differences; separate analyses of data from $\mathrm{J}_{\mathrm{rec}}$ and $\mathrm{J}_{\text {all }}$ also facilitated the comparison

257 of trends in E. epiphron and in E. sudetica, because the latter was monitored only during the 258 recent period (2009-2020).

259 We used an information theoretic approach, which is more appropriate for comparing large 260 numbers of models with different predictors than a frequentist hypothesis testing (Symonds \&

261 Moussalli, 2011). Understanding that climate variables are always causally interdependent and

262 numerically intercorrelated, and given the rather low degrees of freedom ( $3 / 4$ transects for $\mathrm{J} / \mathrm{K} \mathrm{x}$

$26311 / 12 / 15$ monitoring years for $\mathrm{K} / \mathrm{J}_{\text {rec }} / \mathrm{J}_{\text {all }}$ ), we did not fit models with multiple predictors and their

264 interactions, as this would risk overfitting and unreliable estimates (Harrell, 2015). Instead, we

265 evaluated individual predictors separately.

266 We used GLM with population abundance index (PAI, log-transformed) per year and

267 transect as the response variable and transect as a fixed factor. The predictors were standardised

268 to zero mean and unit variance, which enabled relative comparisons of their effects. The

269 residuals were checked against the predicted values using simulateResiduals in DHARMa for R

270 (Hartig, 2016).

271 We first constructed, for each of the four data sets , a null model not containing

272 predictors: $\log (P A I) \sim 1+$ Transect. Its $A I C$ was used to evaluate subsequently fitted models

273 according to $\triangle A I C$ between the null and a fitted model(s). We considered $\triangle A I C<-6$ a strong and

$274<-2$ a moderate indication of an effect of the respective predictor (Richards et al., 2011). 
275 Because population abundances may reflect dependence on previous years, we tested for the 276 presence of a temporal autocorrelation using the corAR1 function (autocorrelation structure of 277 order 1). For all data sets, the null models without autocorrelation had smaller AICs than those 278 with autocorrelation, and we did not consider autocorrelation further. We used an analogous procedure for flight period Onset and Duration. We did not consider autocorrelation with the previous year, as there is no reason to expect dependency of 281 flight timing on the previous year abundance.

\section{Results}

In $\mathrm{J} / \mathrm{K}$, we walked 544/646 transect walks (mean \pm SD: $32 \pm 14.8 / 65 \pm 14.4$ ), obtaining 3,827 records of E. sudetica, 12,137 records of E. epiphron J, and 14,010 records of E. epiphron K (Supporting Information, Table S1). Raw data are available in Figshare at https://doi.org/10.6084/m9.figshare.14642472.

\section{Correlations among variables}

292 We found a strong negative correlation between the flight period Onset and Duration in E.

293 sudetica $(r=-0.70,95 \%$ confidence interval $=[-0.84,-0.48])$, E. epiphron, $\mathrm{J}\left(\mathrm{J}_{\mathrm{all}}: r=-0.73,[-\right.$ resulted in longer duration of the flight period. In E. sudetica and E. epiphron Jeseniky Mts., the relative abundance $(P A I)$ significantly increased with Duration but was not affected by Onset

297 (Table 1, Supporting information Fig. S17). Some of the climate variables were correlated, in 
298 particular different temperature variables within individual parts of the year (e.g., $T_{\text {avg }}$ Win and

$299 T_{\min }$ Win) (Supporting information, Figs. S12-S16).

300

301 Temporal trends

302 We detected several temporal trends in climate variables over the entire study period in $\mathrm{J}_{\text {all }}$ (i.e.,

303 including the 1990s data), but most of them were not apparent over the shorter recent period $\left(\mathrm{J}_{\text {rec }}\right.$

304 and $\mathrm{K}$ ). Specifically, most measures of temperature increased in $\mathrm{J}_{\text {all }}$, winter precipitation

305 increased in $\mathrm{J}_{\mathrm{rec}}$, and summer precipitation decreased in $\mathrm{K}$. The trends in these variables were

306 similar in both mountains, but often weak in terms of statistical significance (Supporting

307 information, Table S2).

308 Despite large inter-annual variation, adult abundance significantly increased in $E$.

309 sudetica $\mathrm{J}$ and E. epiphron K, but not in E. epiphron J (Table 2, Fig. 2). There was no temporal

310 trend in Onset (Supporting information, Fig. S18) and in most cases in Duration (Fig. S19, Table

311 2) with the exception of E. epiphron $\mathrm{J}_{\text {all }}$, for which the flight period Duration increased since the

312 1990s (Fig. S19). E. epiphron K displayed an evidence of biennial fluctuations, with population

313 abundance index $\approx 1.8$ times higher in odd years than in even years (GLM, the model including

314 the odd/even year had $\triangle A I C=-4.7$ compared to the null model), but no such pattern applied for

315 either of the species in $\mathrm{J}$.

316

317 Climate variables and abundance

318 In E. sudetica, warmer autumns ( $\left.T_{\min } A u t, T_{\text {ground } A u t}\right)$, higher winter precipitation $\left(P_{\text {tot }}\right.$ Win $)$ and

319 higher spring temperatures $\left(T_{\min } S p r, T_{\max } S p r, T_{a v g} S p r\right)$ increased $P A I$ in the following year. In 
320 contrast, increasing spring precipitation $\left(P_{t o t} S p r\right)$ and increasing minimum summer temperatures

321 ( $T_{\min }$ Sum $)$ decreased population abundance index in the following year (Table 3).

322 For E. epiphron J, adult population abundance index increased with autumn temperatures

$323\left(T_{\min } A u t, T_{\text {ground }} A u t\right)$, winter precipitation $\left(P_{t o t}\right.$ Win $)$ and spring temperatures $\left(T_{a v g} S p r, T_{\max } S p r\right.$,

$324 T_{\min } \mathrm{Spr}$ ), but decreased with winter temperatures in $\left(T_{\text {avg }}\right.$ Win $)$ (Table 3$)$ and higher summer

325 minimum ground temperatures $\left(T_{\text {ground }}\right.$ Sum $)$. The negative effect of winter temperatures $\left(T_{\text {avg }}\right.$ Win,

$326 T_{\min }$ Win, $T_{\text {ground }}$ Win) was more distinct for $\mathrm{J}_{\text {rec }}$ than for $\mathrm{J}_{\text {all }}($ Table 3$)$. For $\mathrm{J}_{\text {rec }}, T_{\min }$ Win and

$327 T_{\min }$ Sum displayed moderate effects, not detected for $\mathrm{J}_{\text {all }}$.

328 For E. epiphron $\mathrm{K}$, the predictors increasing subsequent population abundance index

329 consistently with E. epiphron $\mathrm{J}$ were higher autumn temperatures $\left(T_{\min } A u t\right)$, higher winter

330 precipitation $\left(P_{t o t}\right.$ Win $)$, and higher spring temperatures $\left(T_{\text {avg }} \mathrm{Spr}\right)$ (Fig. 3). The negative effect of

331 warm winters, prominent in $\mathrm{J}$, was not detected in $\mathrm{K}$. Another difference was higher precipitation

332 in summer $\left(P_{\text {tot }}\right.$ Sum $)$, reducing adult abundances in $\mathrm{J}(\triangle A I C<-2)$ but not in $\mathrm{K}$. The major trends

333 of warm springs increasing adult abundance, and winters with little precipitation decreasing it,

334 were consistent for the two mountains (Table 3).

335

336 Climate variables and phenology

337 Adult phenology of E. sudetica (Table S3, Figs. 4-5) was affected by climate in all larval phases.

338 Higher autumn ground temperatures $\left(T_{\text {ground }} A u t\right)$ advanced Onset, i.e., accelerated larval

339 development. Higher spring precipitation $\left(P_{t o t} S p r\right)$ postponed Onset and shortened Duration.

340 Warm springs ( $T_{a v g} S p r, T_{\max } S p r, T_{\min } S p r$ ) advanced Onset and prolonged Duration. Summer

341 weather had no effect on Duration (Table S3). 
In E. epiphron J, warmer autumns ( $\left.T_{\min } A u t, T_{\text {ground }} A u t\right)$ and springs $\left(T_{\text {avg }} S p r\right)$ advanced

343 Onset (Table S43 Fig. 4) and prolonged Duration. Higher spring precipitation $\left(P_{t o t} S p r\right)$ had

344 opposite effects. In summer, flight period Duration increased with $T_{\text {avg }}$ Sum.

345 In E. epiphron K, the factors affecting phenology partly differed from J, but there were

346 commonalities (Table S3, Figs. 4-5). As in J, rainy springs ( $\left.P_{t o t} S p r\right)$ delayed Onset and shortened

347 Duration, whereas warm springs ( $\left.T_{\text {avg }} S p r, T_{\min } S p r\right)$ advanced Onset. Contrary to J, warm

348 autumns $\left(T_{\max } A u t\right)$ delayed and rainy autumns $\left(P_{t o t} A u t\right)$ advanced Onset. In addition, warm

349 winters $\left(T_{a v g}\right.$ Win,$T_{\min }$ Win $)$ and summers $\left(T_{\max }\right.$ Sum $)$ shortened Duration, which was not detected

350 in $\mathrm{J}$ (Table S3).

351

352 Discussion

353

354 Fitting indices of the abundance and phenology of two subalpine butterflies obtained by a decade

355 of detailed monitoring to climate data revealed patterns remarkably consistent between $E$.

356 epiphron, a species of wind-exposed flat summit grasslands, and E. sudetica, a species associated

357 with tall-herb vegetation of leeward sites near the timberline. For the former, the patterns were

358 also mostly consistent between two mountain systems, isolated by more than $100 \mathrm{~km}$. In both

359 species, higher winter temperatures and lower precipitation (i.e., less snow) experienced by

360 overwintering larvae diminish subsequent adult abundance (cf. Rytteri, 2021), whereas warmer

361 autumns, and warmer and drier springs, increase it (Table 3, Fig. 4). Warm autumns and springs

362 also advance the adult flight onset, which is positively linked to flight duration (Table S3. These

363 observations were made against a background of generally increasing temperatures (Migala et 
364 al., 2016) in both mountain ranges, and against stable (E. epiphron, J) or increasing (E. sudetica,

365 J, E. epiphron, K) population trends (Fig. 2).

366 The results have profound implications for the studied species and mountain insects in

367 general. Warmer autumns and springs appear beneficial for subsequent adult abundances,

368 presumably via increased larval survival. These effects are counteracted by low winter

369 precipitation and high winter temperatures, implying low snow cover.

370 For hibernating insects, lack of snow worsens the insulation of the ground layer, exposing

371 them to deep frosts (Huang, 2016). Interestingly, Vrba et al. (2012) reported that E. epiphron and

372 E. sudetica had higher values of lower lethal temperatures than their lowland congeners. This

373 suggests that they may be more sensitive to frosts, because they are adapted to predictable winter

374 conditions in the mountains where the ground is insulated by snow for the entire winter, unlike in

375 the lowlands where frosty periods without snow are common (Vrba et al., 2012). Warm periods

376 during winter may increase overwintering insect mortality due to fungal infections (Steenberg \&

377 Ogaard, 2000), diapause breakups (Lindestad et al., 2020), or metabolic failures (Klockmann \&

378 Fischer, 2019). Overwintering without snow in combination with advanced spring onset

379 decreased overwintering survival in Melitaea cinxia (Rytteri, 2021). However, E. epiphron and

380 E. sudetica were not affected by snow cover duration (Snow days ) based on our results (Table 3 ).

381 Warm autumns and springs had opposite effects than warm winters, increasing adult

382 abundances, advancing adult flight onsets and extending their durations. Warm conditions during

383 larval feeding periods may accelerate the development (Roy et al., 2001) and shorten the

384 exposure to natural enemies (Culler et al., 2015). Increased pre-hibernation food intake may

385 improve the larval energy budget, allowing synthesis of more cryoprotective compounds (Vrba

386 et al., 2017a). An identical logic likely applies to post-hibernation larvae, in which the warmer 
387 and drier weather accelerates development, advancing the flight onsets (Gutiérrez \& Wilson,

388 2020; Stewart et al., 2019). The beneficial effects of warmer temperatures apply only up to

389 species-specific limits, set by heat tolerance (Terblanche et al., 2017), diapause/moulting triggers

390 (Gonzalez-Tokman et al., 2020), or thermal effects mediated via host plants (Barrio et al., 2015).

391 Caterpillar feeding may be impaired by temperatures above their thermal limits (Klockmann et

392 al., 2018), and feeding efficiency may decline with increased respiration rates (Bauerfeind \&

393 Fischer, 2013; Kukal \& Dawson, 1989). As we found no negative effects of warm autumns or

394 springs, we presume that the warmer conditions of the last decade had not yet exceeded the

395 studied species' thermal optima.

396 During adult flight, high minimum temperatures decreased both species' abundances.

397 This puzzling effect is likely linked to the summer mountain climate with cold nights and

398 mornings during high-pressure periods (warm days), and warm nights and mornings during

399 foggy low-pressure periods (cold days). Foggy weather leaves insects defenceless to warm-

400 blooded predators (birds, small mammals) and may cause starvation of adults. Weather effects

401 on lepidopteran adult longevity and population dynamics remain little explored (cf. Bubova et

402 al., 2016), and deserve attention in mountain environments (Junker et al., 2010).

403 The mechanisms extending flight duration following warmer larval conditions (Table S4)

404 appear less straightforward. Univoltine butterflies of Sierra de Guadarrama, Spain, advanced

405 flight onset after warm springs, but this was not always connected with increased abundances

406 (Stewart et al. 2020). Zografou et al. (2020) observed delayed flight onsets and shorter durations

407 in higher elevations of two Greek mountain systems. In the Erebia butterflies studied here,

408 warmer conditions during larval feeding periods may support larval growth, extending adult

409 longevity. Alternatively, warmer conditions may desynchronise larval development, causing 
410 gradual adult emergence in low densities rather than abrupt emergence in high densities ( $c f$. Ehl

411 et al., 2017). Also recall that Erebia spp. can be flexible regarding the larval development

412 duration (Wipking \& Mengelkoch, 1994). The development of E. epiphron lasted a single season

413 in lowland outdoor conditions (Kuras et al., 2001), but it takes two seasons in the Alps

414 (Sonderegger, 2005). We did not detect indications of biennial development in J, but detected

415 them in $\mathrm{K}$. The latter mountains are only $\approx 100 \mathrm{~m}$ higher, but are situated more westerly, exposed

416 directly to winds blowing from the North Sea over the German Plains. Still, the E. epiphron

417 biannual fluctuations in $\mathrm{K}$ were less prominent than in a related species E. euryale with

418 prevailing biennial development (Kleckova et al., 2015). Possibly, the development length varies

419 among individuals, lasting one or two years according to the local conditions. If so, warm

420 weather during larval periods may allow for pupation in some larvae that would otherwise

421 develop for an additional season. These butterflies would emerge relatively late in the flight

422 period, optically prolonging its duration. The positive relationship between flight duration and

423 population abundance index call for the latter possibility.

424 The positive effects of increasingly warm autumns and springs likely counteract the

425 negative effects of snowless winters on the Erebia butterflies' population dynamics. Remarkably

426 similar patterns apply to other alpine insects. Roland \& Matter (2016) found, for the butterfly

427 Parnassius smintheus Doubleday, 1847 in the Canadian Rocky Mts, negative effects of

428 November temperature extremes, and positive effects of warm springs. November (i.e., early

429 winter) snow cover was the best predictor of the following seasons' abundances (Roland et al.,

430 2020). Climate effects differing across species or phenotypes were demonstrated by Buckley \&

431 Kingsolver (2012), who modelled the interaction between the time available for flight and egg

432 viability in two alpine Colias spp. in the Rocky Mts, USA. In cooler conditions, the two species 
433 differed in their ability to respond by extension of the flight period, which should balance the

434 decreased egg viability caused by weather extremes. Beyond insects, Chirichella et al. (2020)

435 found that better forage availability during warm winters increases the reproductive output of the

436 alpine chamois (Rupicapra rupicapra), but this effect was outweighed by the negative effects of

437 decreased forage quality during warm summers. Outside of high mountains, Long et al. (2017)

438 detected warm winters as detrimental and hot summers as beneficial for the majority of British

439 butterflies, whereas cold winters and cold summers had the opposite effects. All these studies

440 warn against simplistic assumptions of climate effects on alpine fauna based on single measures,

441 such as mean annual temperatures.

442 Warmer and drier autumns and springs allow building up population numbers, likely

443 buffering the populations against the detrimental effects of snowless winters. The increasing

444 yearly population numbers of E.sudetica and E. epiphron suggest that the positive effects of the

445 warmer vegetation season currently prevail. However, we observed a notable drop in their

446 numbers in 2020 , a year with a low amount of snow in the winter followed by a rainy summer

447 (Fig. 2). Population numbers are thus reflecting ongoing climatic change (warmer vegetation

448 season) and stochastic fluctuations of local precipitation (Migala et al., 2016). The effect of these

449 factors is complex and may be driven by interactions between precipitation and temperature

450 (Rytteri, 2021). Longer-term monitoring data will be needed to provide more detailed insight.

451 As a rule, climate variation is buffered by diverse microclimates in mountain

452 environments (Niento-Sanchez et al., 2015; Roland et al., 2020; Turlure et al., 2010; Wilson et

453 al., 2015) and the more abundant a population, the more individuals will likely locate

454 microclimatically suitable sites. This provides grounds for moderate optimism regarding the

455 future of the studied populations and other insects of temperate zone middle-high mountains. In 
456 addition, in both the Jeseník and Krkonoše mountains, the timberline elevation had fluctuated

457 during the Holocene, rising to higher elevations than at present, e.g., during the Atlantic period, 458 and descending due to booming pastoralism in the early modern era (Treml et al., 2016). The

459 studied butterflies persisted through these fluctuations (Schmitt et al., 2005), arguably owing to

460 non-trivial population-level responses to fluctuating climate and habitat availability. However,

461 while microclimate variability may facilitate the survival of these mountain populations, the

462 availability of suitable habitats will strongly depend on the management of mountain grasslands,

463 such as appropriate levels of grazing and suppression of expanding Pinus mugo brushwood (cf.

464 Bila et al., 2016; Zeidler et al., 2021).

465

466 Conclusions

467 We used data from long-term monitoring of mountain butterflies to understand the effect of

468 climate change on mountain biological systems. The adult population abundances are driven by

469 conditions experienced during their development. Warmer autumns and springs as well as high-

470 precipitation winters experienced by larvae were reflected by higher adult population numbers of

471 adult butterflies in subsequent summers. The adult population abundances were stable or even

472 increasing in our study system. Thus, the positive and negative effects of climatic conditions

473 experienced during development are in balance. We highlight that the observed positive

474 population trends could be misleading as several years with adverse combinations of climatic

475 conditions can lead to the collapse of local populations surviving on relatively small areas in

476 low-elevation mountains. The long-term survival of mountain invertebrates can be supported by

477 careful management, particularly by blocking of the encroachment of subalpine and alpine

478 grasslands by trees and shrubs. 


\section{Acknowledgements}

483 We are grateful to dozens of students of the University of South Bohemia and volunteers for 484 participation in the monitoring, the Jeseník Protected Landscape Area and Krkonoše National 485 Park for logistic support, M. Sweney for linguistic corrections and the Czech 486 Hydrometeorological Institute for climate data. Permissions for the field research were obtained 487 from the administration of the Jeseníky Protected Landscape Area and the administration of the 488 Krkonoše National Park.

\section{References}

492

Ayers, M. P. \& Scriber, J. M. (1994). Local adaptation to regional climates in Papilio canadensis (Lepidoptera, Papilionidae). Ecological Monographs, 64, 465-482.

Barrio, I. C., Bueno, C. G. \& Hik, D. S. (2016). Warming the tundra: reciprocal responses of invertebrate herbivores and plants. Oikos, 125, 20-28.

Bauerfeind, S. S. \& Fischer, K. (2013). Increased temperature reduces herbivore host-plant quality. Global Change Biology, 19, 3272-3282. butterflies and moths from the spread of Pinus mugo into the alpine zone in the High Sudetes Mountains. PEERJ, 4, e2094. 
502 Boggs, C. L. \& Murphy, D. D. (1997). Community composition in mountain ecosystems:

503 climatic determinants of montane butterfly distribution. Global Ecology and.

504 Biogeography Letters, 6, 39-48.

505 Bubova, T., Kulma, M., Vrabec, V. \& Nowicki, P. (2016). Adult longevity and its relationship

506 with conservation status in European butterflies. Journal of Insect Conservation, 20, $507 \quad 1021-1032$.

508 Buckley, L. B. \& Kingsolver, J. G. (2012). The demographic impacts of shifts in climate means 509 and extremes on alpine butterflies. Functional Ecology, 26, 969-977.

510 Bures, L. (2018). Fenomén Velká kotlina 3. Voda, sníh a laviny. [The Velká Kotlina cirque

511 phenomenon 3. Water, snow and avalanches]. Živa, 3/2018, 16-20.

512 Chirichella, R., Stephens, P. A., Mason, T. H. E. \& Apollonio, M. (2020). Contrasting effects

513 of climate change on alpine chamois. Journal of Wildlife Management, 85, 109-120.

514 Cizek, O., Malkiewicz, A., Beneš, J. \& Tarnawski, D. (eds) (2015). Denní motýli v Krkonošich, 515 atlas rozšírení - Motyle dzienne w Karkonoszach, atlas rozmieszczenia. Správa KRNAP $516 \quad \&$ Direkcja KPN, 328 pp.

517 Corcos, D., Cerretti, P., Mei, M., Vigna Taglianti, A., Paniccia, D., Santoiemma, G., De Biase, 518 A \& Marini, L. (2018). Predator and parasitoid insects along elevational gradients: role of 519 temperature and habitat diversity. Oecologia, 188, 193-202.

520 Culler, L. E., Ayres, M. P. \& Virginia R.A. (2015). In a warmer Arctic, mosquitoes avoid 521 increased mortality from predators by growing faster. Proceedings of the Royal Society 522 B Biological Sciences, 282, 20151549.

523 Cuvelier, S. \& Dinca,V. (2007). New data regarding the butterflies (Lepidoptera: Rhopalocera) of Romania, with additional comments (general distribution in Romania, 
habitat preferences, threats and protection) for ten localized Romanian species. Phegea $35,93-115$

527

528

529

530

531

532

533

534

535

536

537

538

539

540

541

542

543

544

545

546

547

Davies, W. J. (2019). Multiple temperature effects on phenology and body size in wild butterflies predict a complex response to climate change. Ecology, 100, e02612.

Dray, S. (2008). On the number of principal components: A test of dimensionality based on measurements of similarity between matrices. Computational Statistics \& Data Analysis, 52, 2228-2237.

Ehl, S., Ebertshauser, M., Gros, P. \& Schmitt, T. (2017). Population demography of alpine butterflies: Boloria pales and Boloria napaea (Lepidoptera: Nymphalidae) and their specific adaptations to high mountain environments. Acta Oecologica, 85, 53-61.

Ewing, S. R., Menéndez, R., Schofield, L. \& Bradbury, R. B. (2020). Vegetation composition and structure are important predictors of oviposition site selection in an alpine butterfly, the Mountain Ringlet Erebia epiphron. Journal of Insect Conservation, 24, 445-457.

Franco, A. M. A., Hill, J. K., Kitschke, C., Collingham, Y. C., Roy, D. B., Fox, R., Huntley, B. \& Thomas, C. D. (2006). Impacts of climate warming and habitat loss on extinctions at species' low-latitude range boundaries. Global Change Biology, 12, 1545-1553.

Freeman, B. G., Lee-Yaw, J. A., Sunday, J. M. \& Hargreaves, A. L. (2018). Expanding, shifting and shrinking: The impact of global warming on species' elevational distributions. Global Ecology and Biogeography, 27, 1268-1276.

Garcia-Gonzalez, R. (2008). Management of Natura 2000 habitats. 6170 Alpine and subalpine calcareous grasslands. European Commission. http://hdl.handle.net/10261/36593

Gonzalez-Tokman, D., Cordoba-Aguilar, A., Dattilo, W., Lira-Noriega, A., Sanchez-Guillen, R. A. \& Villalobos, F. (2020). Insect responses to heat: physiological mechanisms, 
evolution and. ecological implications in a warming world. Biological Reviews, 95, 802821.

Grill, A., Polic, D., Guariento, E. \& Fiedler, K. (2020). Permeability of habitat edges for Ringlet butterflies (Lepidoptera, Nymphalidae, Erebia Dalman 1816) in an alpine landscape. Nota Lepidopterologica, 43, 29-41.

Gutiérrez, D. \& Wilson, R. J. (2020). Intra- and interspecific variation in the responses of insect phenology to climate. Journal of Animal Ecology, 90, 248-259.

Hanski, I. (1999). Metapopulation ecology. Oxford University Press, Oxford.

Haubrich, K. \& Schmitt, T. (2007). Cryptic differentiation in alpine-endemic, high-altitude butterflies reveals down-slope glacial refugia. Molecular Ecology, 16, 3643-3658.

Harrell Jr, F. E. (2015). Regression modeling strategies: with applications to linear models, logistic and ordinal regression, and survival analysis. Springer.

Hartig, F. (2016). DHARMa: residual diagnostics for hierarchical (multi-level/mixed) regression models. $\mathrm{R}$ package version 0.1 .0

Hinojosa, J. C., Monasterio, Y., Escobes, R., Dinca, V.\& Vila, R. (2018). Erebia epiphron and Erebia orientalis: sibling butterfly species with contrasting histories. Biological Journal of the Linnean Society, 126, 338-348.

Huang, J. J. (2016). Effects of soil temperature and snow cover on the mortality of overwintering pupae of the cotton bollworm, Helicoverpa armigera (Hubner) (Lepidoptera: Noctuidae). International Journal of Biometeorology, 60, 977-989. reproductive success in Bicyclus anynana butterflies. Journal of Thermal Biology, 36, 283-287. 
571 Junker, M., Wagner, S., Gros, P. \& Schmitt, T. (2010). Changing demography and dispersal

572 behaviour: ecological adaptations in an alpine butterfly. Oecologia, 164, 971-980.

573 Karl, I., Stoks, R., De Block, M., Janowitz, S.A. \& Fischer, K. (2011). Temperature extremes and butterfly fitness: conflicting evidence from life history and immune function. Global Change Biology, 17, 676-87.

Kasak, J., Mazalova, M., Sipos, J. \& Kuras, T. (2015). Dwarf pine: invasive plant threatens biodiversity of alpine beetles. Biodiversity and Conservation, 24, 2399-2415.

Kaspar, J., Hosek, J. \& Treml, V. (2017). How wind affects growth in treeline Picea abies. Alpine Botany, 127, 109-120.

Kleckova, I., Konvicka, M. \& Klecka, J. (2014). Thermoregulation and microhabitat use in mountain butterflies of the genus Erebia: Importance of fine-scale habitat heterogeneity.

Kleckova, I., Vrba, P. \& Konvicka, M. (2015). Quantitative evidence for spatial variation in Journal of Thermal Biology, 41, 50-58. the biennial life cycle of the mountain butterfly Erebia euryale (Lepidoptera:

Klockmann, M. \& Fischer, K. (2019). Strong reduction in diapause survival under warm and humid overwintering conditions in a temperate-zone butterfly. Population Ecology, 61, adapted species in isolated mountains: the population genetics of the Sudeten ringlet, 
Erebia sudetica sudetica, in the Jesenik Mts., Czech Republic. Journal of Insect Conservation, 18, 153-161.

Konvicka, M., Benes, J., Cizek, O., Kuras, T. \& Kleckova, I. (2016). Has the currently warming climate affected populations of the mountain ringlet butterfly, Erebia epiphron (Lepidoptera: Nymphalidae), in low-elevation mountains? European Journal of Entomology, 113, 295-301.

Kostal, V., Korbelova, J., Poupardin, R., Moos, M. \& Simek, P. (2016). Arginine and proline 601 applied as food additives stimulate high freeze tolerance in larvae of Drosophila melanogaster. Journal of Experimental Biology, 219, 2358-2367.

Kuras, T., Benes, J., Konvicka, M. \& Honc, L. (2001). Life histories of Erebia sudetica sudetica and E. epiphron silesiana with description of immature stages (Lepidoptera Nymphalidae, Satyrinae). Atalanta, 32, 187-196 + xii.

Kuras, T., Benes, J., Fric, Z. \& Konvicka, M. (2003). Dispersal patterns of endemic alpine butterflies with contrasting population structure. Population Ecology 45, 115-123.

Kuzelova, H. \& Treml, V. (2020). Landscape-scale variability of air and soil temperature related to tree growth in the treeline ecotone. Alpine Botany, 130, 75-87.

613 Lindestad, O., Schmalensee, L., Lehmann, P. \& Gotthard, K. (2020). Variation in butterfly 614 diapause duration in relation to voltinism suggests adaptation to autumn warmth, not winter cold. Functional Ecology, 34, 1029-1040. 
616 Long, O. M., Warren, R., Price, J., Brereton, T. M., Botham, M. S. \& Franco, A. M. A. (2017). Sensitivity of UK butterflies to local climatic extremes: which life stages are most at risk? Journal of Animal Ecology, 86, 108-116.

McLaughlin, J. F., Hellmann, J. J., Boggs, C. L. \& Ehrlich, P. R. (2002). The route to extinction: population dynamics of a threatened butterfly. Oecologia, 132, 538-548.

Migala, K., Urban, G. \& Tomczyński, K. (2016). Long-term air temperature variation in the Karkonosze mountains according to atmospheric circulation. Theoretical and Applied Climatology, 125, 337-351.

Minter, M., Dasmahapatra, K.K., Thomas, C.D., Morecroft, M.D., Tonhasca, A., Schmitt, T., Siozios, S. \& Hill, J.K (2020) Past, current, and potential future distributions of unique genetic diversity in a cold-adapted mountain butterfly. Ecology and Evolution, 10, $11155-11168$.

Nieto-Sanchez, S., Gutierrez, D. Wilson, R. J. (2015). Long-term change and spatial variation in butterfly communities over an elevational gradient: driven by climate, buffered by habitat. Diversity and Distribution, 21, 950-961.

Oksanen, J.F., Blanchet, G., Friendly, M., Kindt, R., Legendre, P., McGlinn, D., ...Wagner H. (2019). vegan: Community Ecology Package. R package version 2.5-6. URL: https://CRAN.R-project.org/package=vegan

Pak, D., Biddinger, D. \& Bjornstad, O. N. (2019). Local and regional climate variables driving spring phenology of tortricid pests: a 36-year study. Ecological Entomology, 44, 367379. 
637 Pauli, H., Gottfried, M., Dullinger, S., Abdaladze, O., Akhalkatsi, M., Benito Alonso, J. L., ...

638 Grabherr, G. (2012). Recent plant diversity changes on Europe's mountain summits.

$639 \quad$ Science, 336, 353-355.

640 Pena, C., Witthauer, H., Kleckova, I., Fric, Z. \& Wahlberg, N. (2015). Adaptive radiations in 641 butterflies: evolutionary history of the genus Erebia (Nymphalidae: Satyrinae). Biological 642 Journal of the Linnean Society, 116, 449-467.

643 Polic, D., Fiedler, K., Nell, C. \& Grill, A. (2016). Mobility of ringlet butterflies in high-elevation 644 alpine grassland: effects of habitat barriers, resources and age. Journal of Insect $645 \quad$ Conservation, 18, 1153-1161.

646 R Core Team (2018). R: A language and environment for statistical computing. R Foundation for 647 Statistical Computing, Vienna. https://www.R-project.org

648 Richards, S., Whittingham, M. \& Stephens, P. (2011). Model selection and model averaging in 649 behavioural ecology: The utility of the IT-AIC framework. Behavioral Ecology and Sociobiology, 65, 77-89.

651 652 653 654 655 656 657

Rothery, P. \& Roy, D. B. (2001). Application of generalized additive models to butterfly transect count data. Journal of Applied Statistics, 28, 897-909.

Radchuk, V., Turlure, C. \& Schtickzelle, N. (2013). Each life stage matters: the importance of assessing the response to climate change over the complete life cycle in butterflies. Journal of Animal Ecology, 82, 275-285.

Roland, J. \& Matter, S. F. (2007). Encroaching forests decouple alpine butterfly dynamics. Proceedings of the National Academy of Sciences, 104, 13702-13704. 
658 Roland, J. \& Matter, S. F. (2016). Pivotal effect of early-winter temperatures and snowfall on population growth of alpine Parnassius smintheus butterflies. Ecological Monographs,

660 $86,412-428$.

661 662 663

Roland, J., Filazzola, A. \& Matter, S. F. (2021). Spatial variation in early-winter snow cover determines local dynamics in a network of alpine butterfly populations. Ecography, 44, 334-343.

Roy, D. B., Rothery, P., Moss, D., Pollard, E. \& Thomas, J. A. (2001). Butterfly numbers and weather: predicting historical trends in abundance and the future effects of climate change. Journal of Animal Ecology, 70, 201-217.

Rytteri S. (2021). Butterflies in changing weather conditions: implications for ecology and conservation. Thesis, Faculty of Biological and Environmental Sciences, University of Helsinki

Scalercio, S., Bonacci, T., Mazzei, A., Pizzolotto, R. \& Brandmayr, P. (2014). Better up, worse down: bidirectional consequences of three decades of climate change on a relict population of Erebia cassioides. Journal of Insect Conservation, 18, 643-650.

Schmitt, T., Cizek, O. \& Konvicka, M. (2005). Genetics of a butterfly relocation: large, small and introduced populations of the mountain endemic Erebia epiphron silesiana. Biological Conservation, 123, 11-18.

Schmitt, T., Habel, J. C., Rodder, D. \& Louy, D. (2014). Effects of recent and past climatic shifts on the genetic structure of the high mountain Yellow-spotted ringlet butterfly Erebia manto (Lepidoptera, Satyrinae): a conservation problem. Global Change Biology, 20, 2045-2061. 
680 Sonderegger, P. (2005). Die Erebien der Schweiz (Lepidoptera: Satyrinae, Genus Erebia). W.

681

682

683

684

685

686

687

688

689

690

691

692

693

694

695

696

697

698

699

700

701

702

Gassmann, Biel, 712+73 pp.

Stalhandske, S., Gotthard, K. \& Leimar, O. (2017). Winter chilling speeds spring development of temperate butterflies. Journal of Animal Ecology, 86, 718-729.

Stewart, J. E., Illan J. G., Richards, S. A., Gutierrez, D. \& Wilson, R. J. (2020). Linking interannual variation in environment, phenology, and abundance for a montane butterfly community. Ecology, 101, e02906.

Symonds, M. R. E. \& Moussalli, A. (2011). A brief guide to model selection, multimodel inference and model averaging in behavioural ecology using Akaike's information criterion. Behavioral Ecology and Sociobiology, 65, 13-21.

Steenberg, T. \& Ogaard, L. (2000). Mortality in hibernating turnip moth larvae, Agrotis segetum, caused by Tolypocladium cylindrosporum. Mycological Research, 104, 87-91.

Tennet, W. J. (2008). A checklist of the satyrine genus Erebia (Lepidoptera) (1758-2006). Zootaxa, 1900, 1-109.

Terblanche, J. S., Mitchell, K. A., Uys, W., Short, C. \& Boardman, L. (2017). Thermal limits to survival and activity in two life stages of false codling moth Thaumatotibia leucotreta (Lepidoptera, Tortricidae). Physiological Entomology, 42, 379-388.

Treml, V., Jankovska, V. \& Petr, L. (2006). Holocene timberline fluctuations in the midmountains of Central Europe. Fennia, 184, 107-119.

Treml, V., Šenfeldr, M., Chuman, T., Ponocná, T., \& Demková, K. (2016). Twentieth century treeline ecotone advance in the Sudetes Mountains (Central Europe) was induced by agricultural land abandonment rather than climate change. Journal of Vegetation Science, 27, 1209- 1221 .

PeerJ reviewing PDF | (2021:05:61457:1:1:NEW 19 Jul 2021) 
703 Turlure, C., Choutt, J., Baguette, M. \& Van Dyck, H. (2010). Microclimatic buffering and

704 resource-based habitat in a glacial relict butterfly: significance for conservation under

705 climate change. Global Change Biology, 16, 1883-1893.

706 Twardosz, R. \& Cebulska, M. (2020). Temporal variability of the highest and the lowest monthly

707 precipitation totals in the Polish Carpathian Mountains (1881-2018). Theoretical and

$708 \quad$ Applied Climatology, 140, 324-341.

709 Vrba, P. Konvicka, M. \& Nedved, O. (2012). Reverse altitudinal cline in cold hardiness among

$710 \quad$ Erebia butterflies. CryoLetters, 33, 251-258.

711 Vrba, P., Dolek, M., Nedved, O., Zahradnickova, Cerrato, C. \& Konvicka, M. (2014).

712 Overwintering of the boreal butterfly Colias palaeno in Central Europe. CryoLetters, 35, $713247-254$.

714 Vrba, P., Nedved, O., Zahradnickova, H. \& Konvicka, M. (2017a). More complex than expected:

715 Cold hardiness and the concentration of cryoprotectants in overwintering larvae of five

716 Erebia butterflies (Lepidoptera: Nymphalidae). European Journal of Entomology, 114,

$717 \quad 470-480$.

718 Vrba, P., Zapletalova, L., Zapletal, M. \& Konvicka, M. (2017b). Pre-winter larval activity and feeding behavior of Erebia aethiops and E. cassioides in Austrian Alps. Biologia, 72, $1334-1340$.

721 Watt, W. B., Wheat, C. W., Meyer, E. H. \& Martin, J. F. (2003). Adaptation at specific loci. VII. Natural selection, dispersal and the diversity of molecular-functional variation patterns among butterfly species complexes (Colias: Lepidoptera, Pieridae). Molecular Ecology, $12,1265-1275$. 
725 Williams, C. M., Marshall, K. E., MacMillan, H. A., Dzurisin, J. D. K. \& Hellmann, J. J. (2012).

726 Thermal variability increases the impact of autumnal warming and drives metabolic

727 depression in an overwintering butterfly. PLOS One, 7, e34470.

728 Wilson, R. J., Bennie, J., Lawson, C. R., Pearson, D., Ortuzar-Ugarte, G. \& Gutierrez, D. (2015).

729 Population turnover, habitat use and microclimate at the contracting range margin of a $730 \quad$ butterfly. Journal of Insect Conservation, 19, 205-216.

731 Wilson, R. J. \& Fox, R. (2020). Insect responses to global change offer signposts for biodiversity and conservation. Ecological Entomology, early access https://doi.org/10.1111/een.12970.

733

Wipking, W. \& Mengelkoch, C. (1994). Control of alternate-year flight activities in high-alpine Ringlet butterflies (Erebia, Satyridae) and Burnet moths (Zygaena, Zygaenidae) from temperate environments. In Danks H.V. (eds): Insect Life-Cycle Polymorphism: Theory, Evolution and Ecological Consequences for Seasonality and Diapause Control. Kluwer Academic Publisher, Dordrecht, pp. 313-347.

Wood, S.N. (2011). Fast stable restricted maximum likelihood and marginal likelihood estimation of semiparametric generalized linear models. Journal of the Royal Statistical Society (B), 73, 3-36.

Zeidler, M., Sipos, J., Banas, M. \& Cernohorsky, J. (2021). The successive trend of vegetation confirms the removal of non-indigenous woody species as an insufficient restoration action. Biodiversity and Conservation, 30, 699-717.

Zografou, K., Grill, A., Wilson, R. J., Halley, J. M., Adamidis, G. C. \& Kati, V. (2020). Butterfly phenology in Mediterranean mountains using space-for-time substitution. Ecology and Evolution, 10, 928-939. 


\section{Figure 1}

A map displaying the transects for monitoring Erebia epiphron and $E$. sudetica in the Jeseník Mts (J1-J3) and E. epiphron in the Krkonoše Mts (K1-K4), Czech Republic.

In the Jeseník Mts, E. epiphron occurs at summit grasslands, whereas E. sudetica inhabits tallherb formations around the timberline, situated at $\approx 1300 \mathrm{~m}$ a.s.l. and formed by dwarf Picea abies trees and occasional patches of non-native Pinus mugo brushwood. In the Krkonoše Mts, the non-native population of E. epiphron descends from the subalpine zone with patches of native $P$. mugo (1200-1500 m a.sl.) to cultural meadows (down to $1100 \mathrm{~m}$ a.s.I.). Map source: Mapy.CZ (CC-BY-SA 4.0).

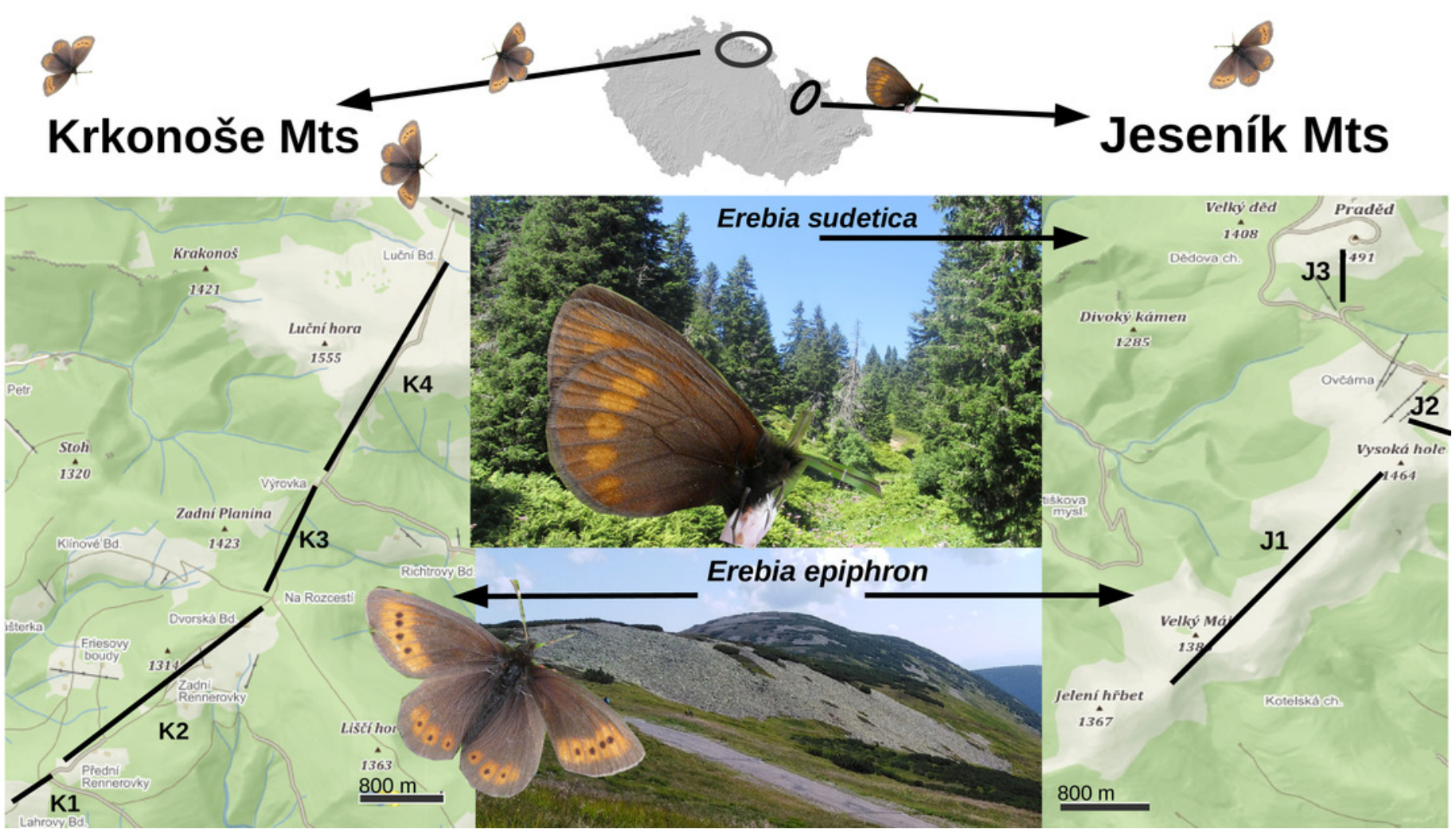


Figure 2

The temporal changes in the abundance index (PAI) of Erebia sudetica and E. epiphron. Colours denote individual transects.

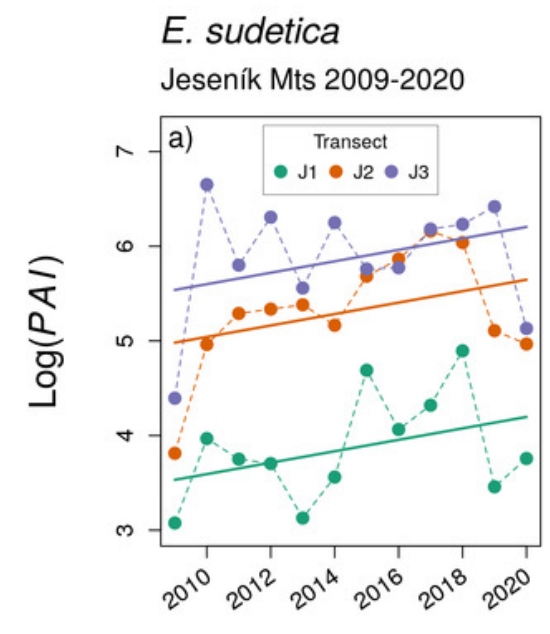

\section{E. epiphron}

Jeseník Mts 1995-1999 and 2009-2020

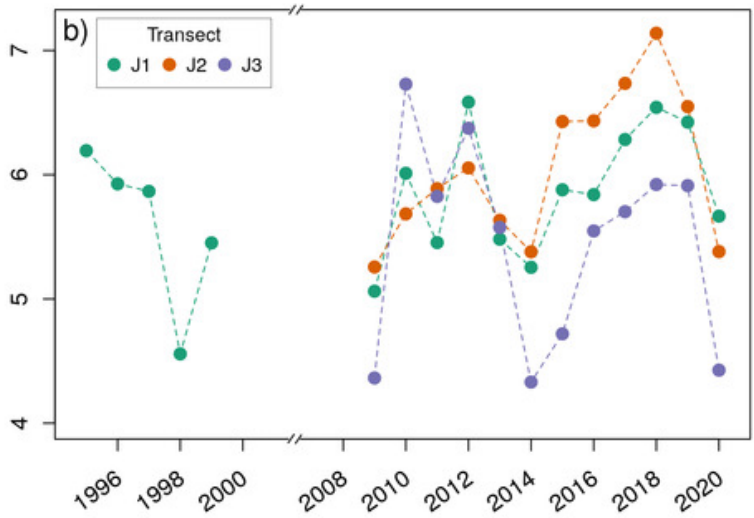

Year

\section{E. epiphron}

Krkonoše Mts 2010-2019

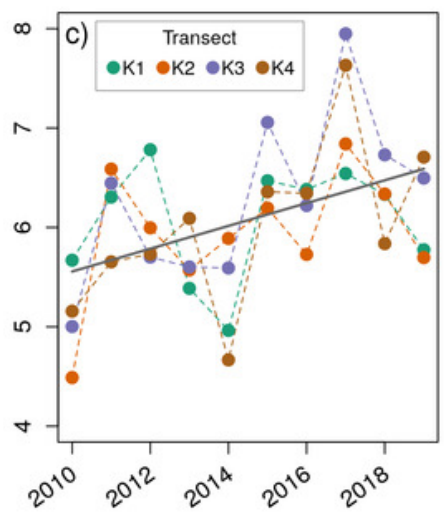




\section{Figure 3}

The effect of climate experienced by larvae during the autumn (Aut), winter (Win), and spring (Spr) on subsequent adult abundances of Erebia sudetica and E. epiphron (the $P A l$ index, see Methods for details).

Climate variables $(\mathrm{T}=$ temperature, $\mathrm{P}=$ precipitation) are shown at their original scale (not standardised) to make the plots more informative. Only selected climate variables are displayed; parameter estimates for all variables are shown in Table 3. See the Methods section for detail description of the climate variables. 
E. sudetica Jeseník Mts 2009-2020
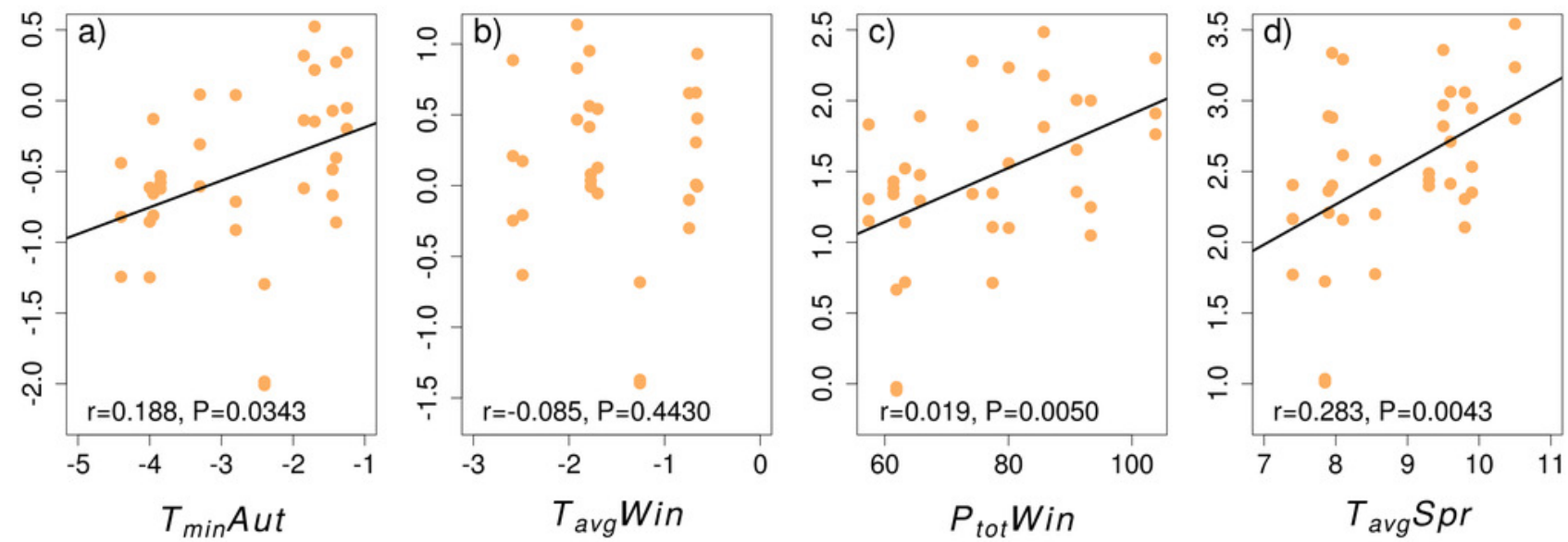

E. epiphron Jeseník Mts 2009-2020

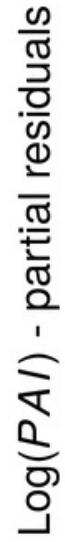
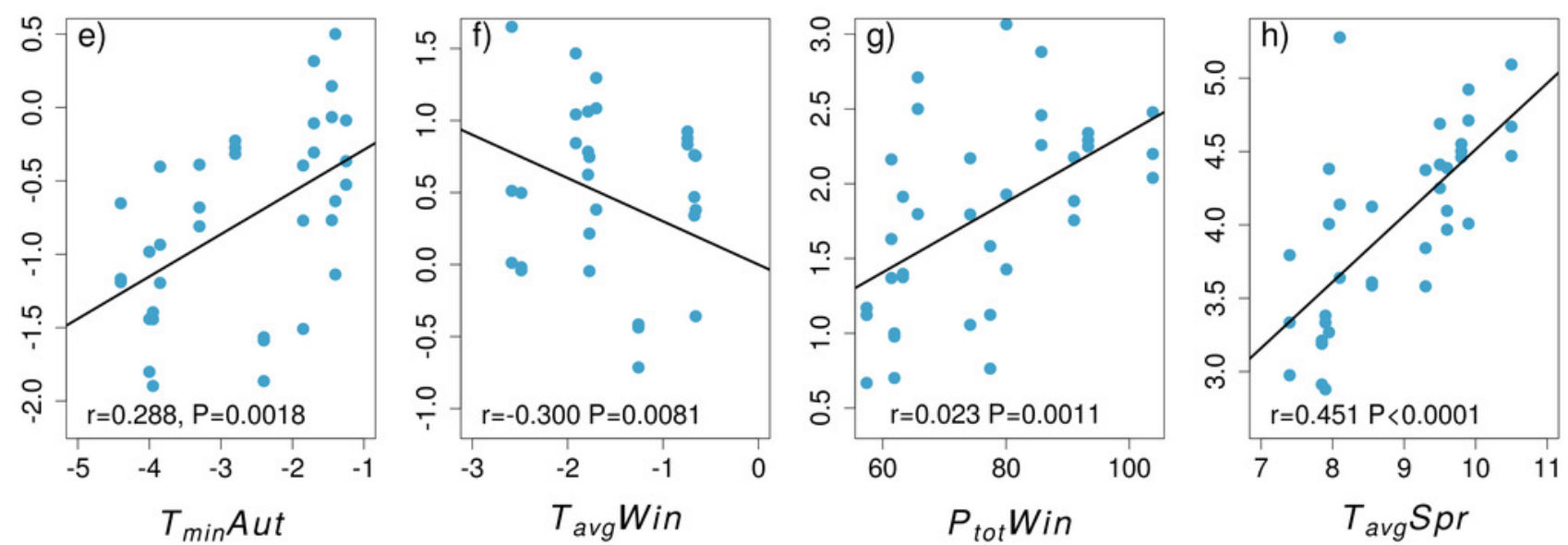

E. epiphron Krkonoše Mts 2010-2019
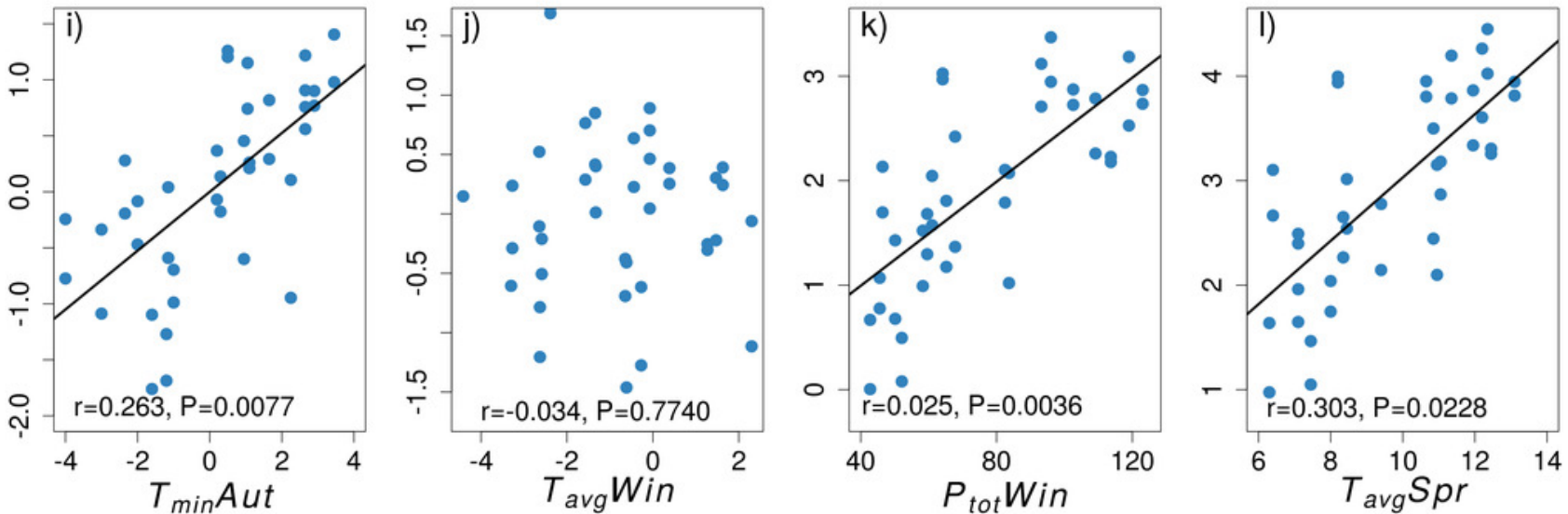


\section{Figure 4}

The effects of the climate variables ( $T=$ temperature, $\mathrm{P}=$ precipitation) experienced by larvae during the autumn (Aut) and spring (Spr) on the onset of the flight period of Erebia sudetica and E. epiphron.

Climate variables are shown at their original scale (not standardised) to make the plots more informative. Only selected climate variables are displayed; parameter estimates for all variables are shown in Table S3. See the Methods section for detailed description of the climate variables. 
E. sudetica Jeseník Mts 2009-2020
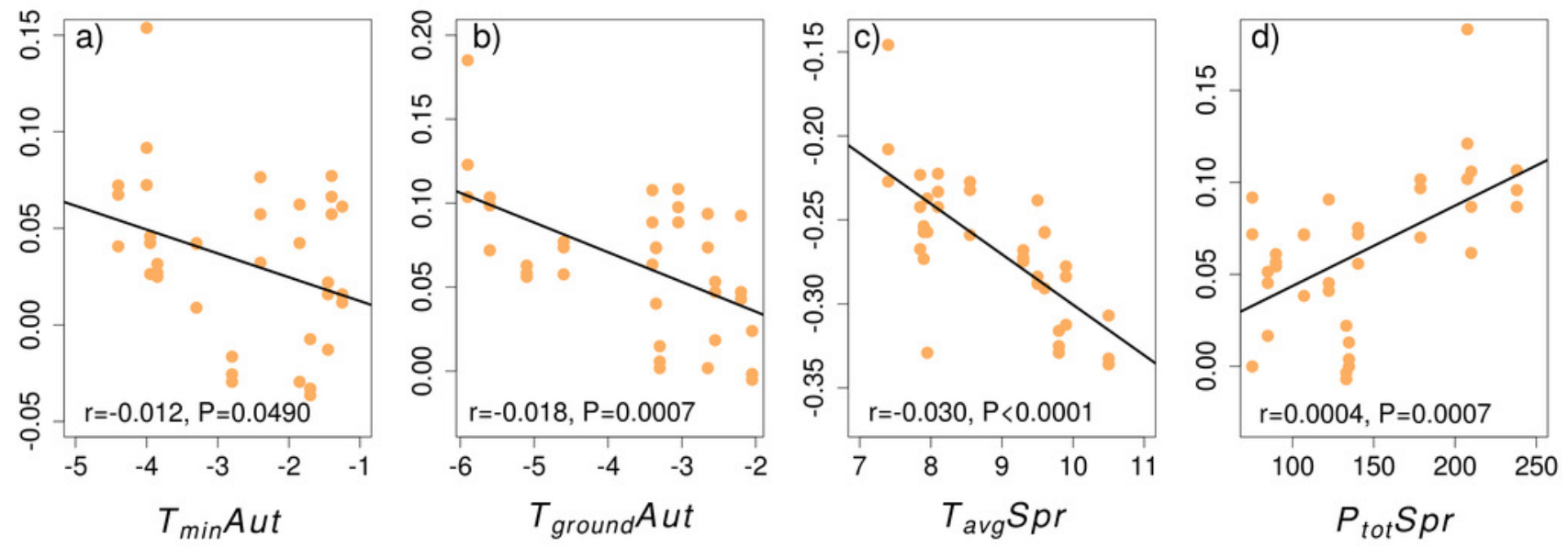

E. epiphron Jeseník Mts 2009-2020
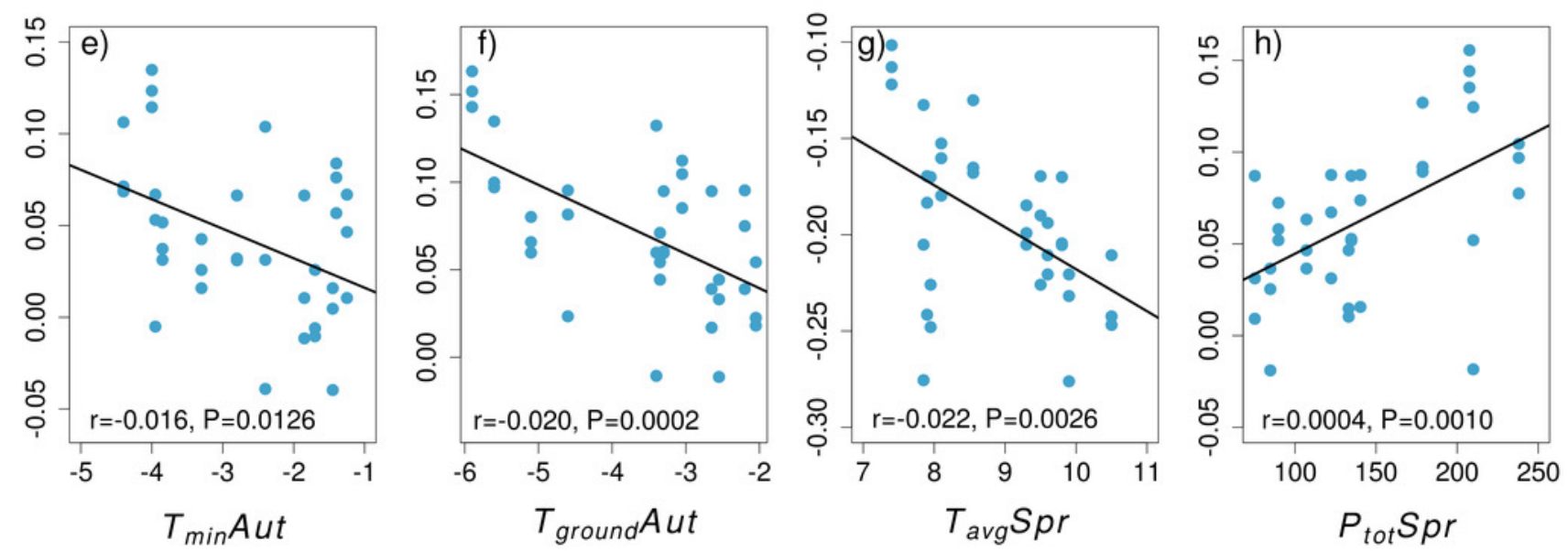

E. epiphron Krkonoše Mts 2010-2019
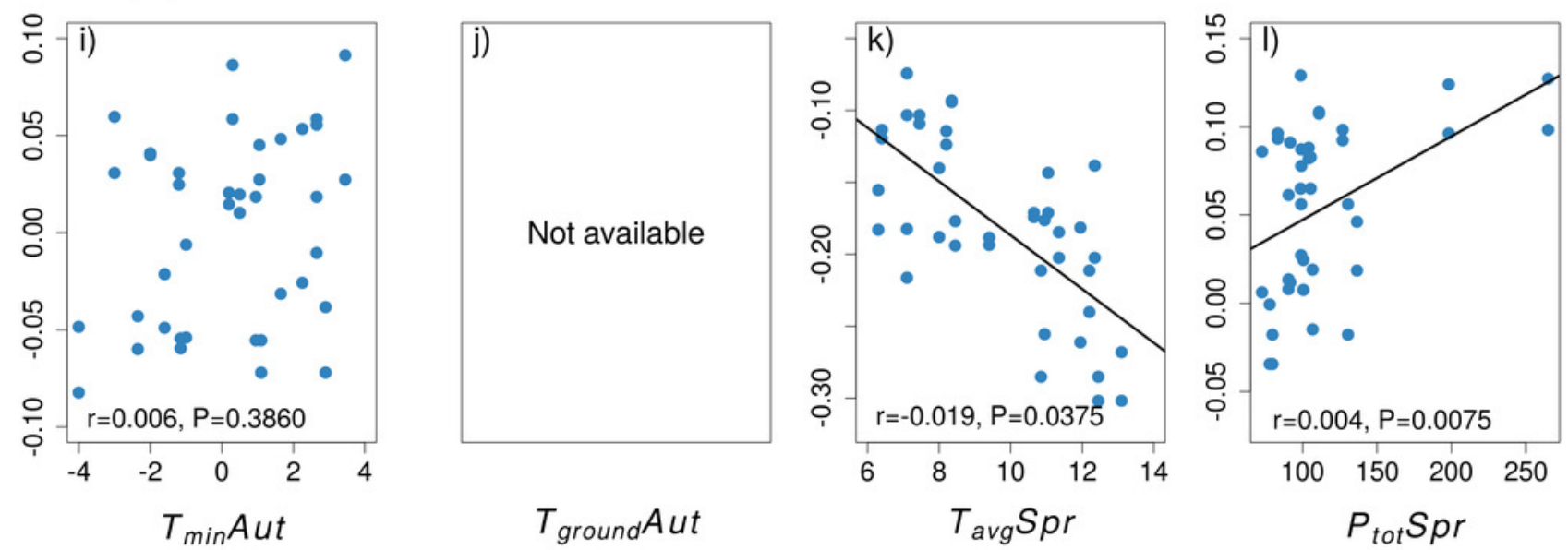


\section{Figure 5}

The effects of the climate variables ( $T=$ temperature, $\mathrm{P}=$ precipitation) experienced by larvae during the autumn (Aut) and spring (Spr) on the duration of the flight period of Erebia sudetica and E. epiphron.

Climate variables are shown at their original scale (not standardised) to make the plots more informative. Only selected climate variables are displayed; parameter estimates for all variables are shown in Table S4. See the Methods section for detailed description of the climate variables. 
E. sudetica Jeseník Mts 2009-2020
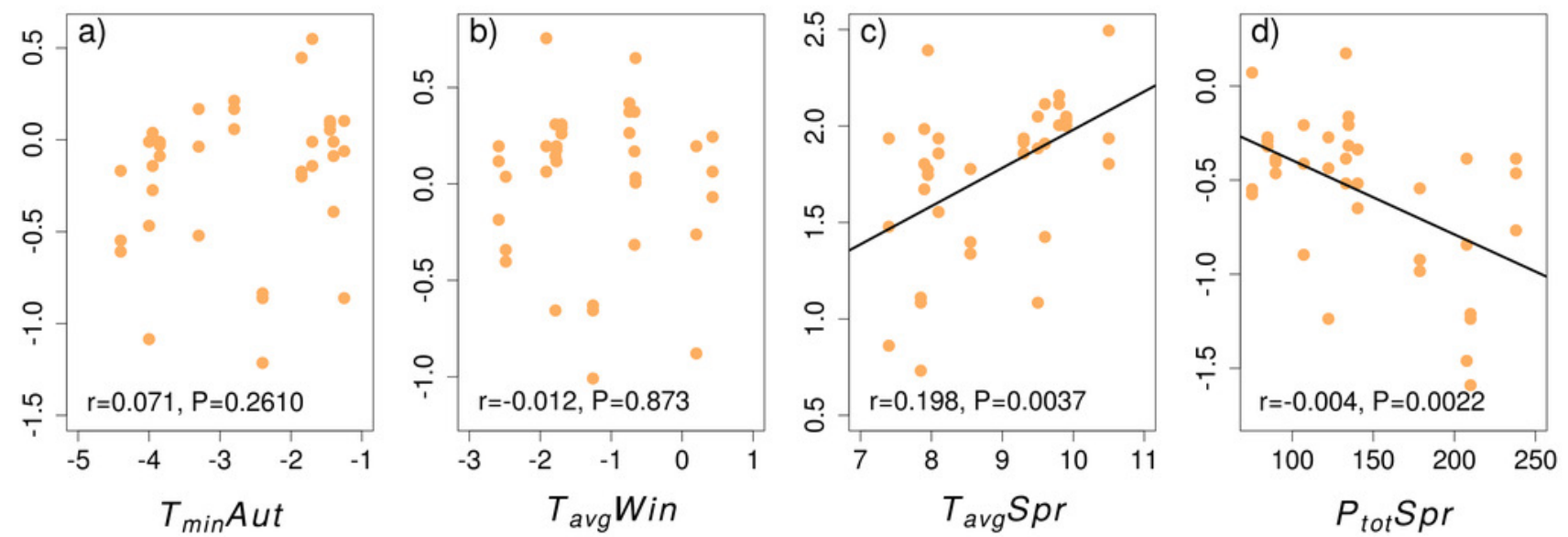

E. epiphron Jeseník Mts 2009-2020
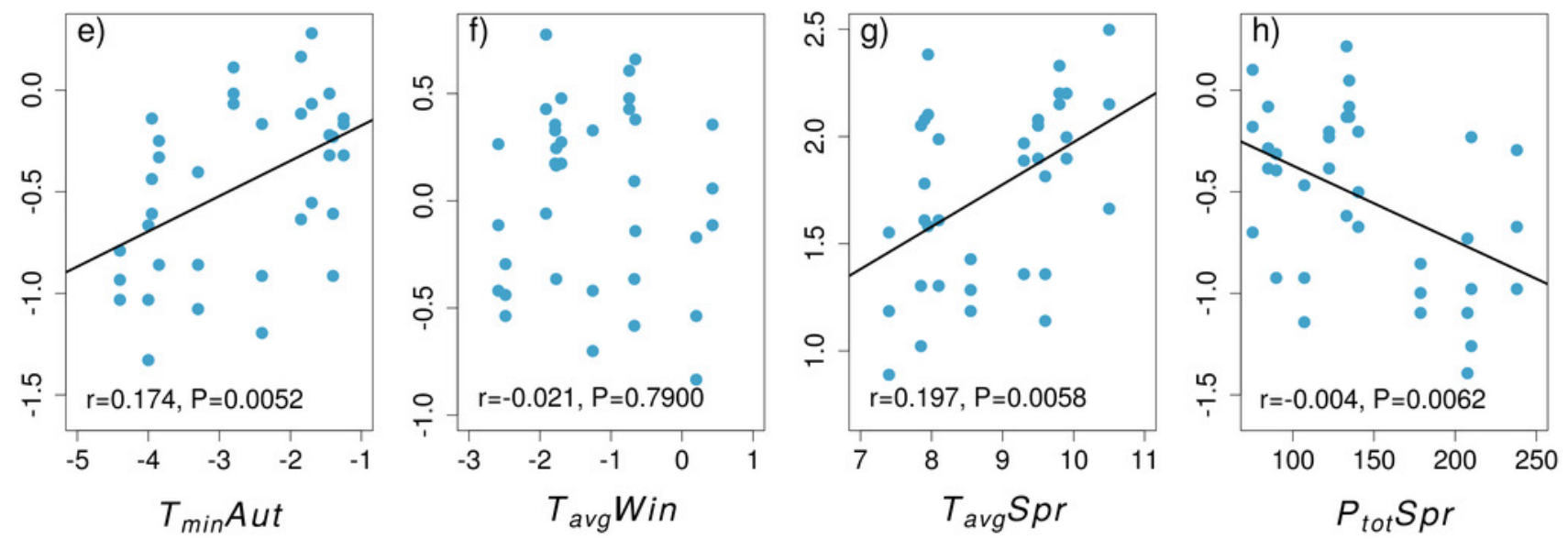

E. epiphron Krkonoše Mts 2010-2019
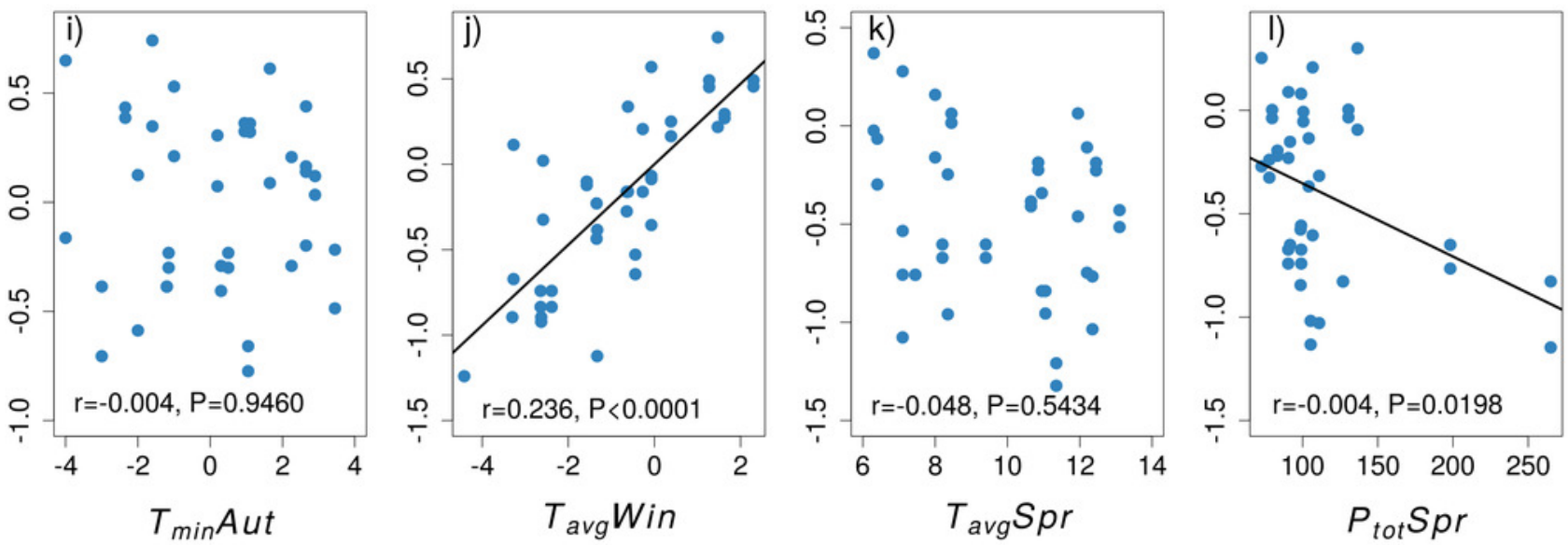


\section{Table $\mathbf{1}$ (on next page)}

The dependence of the population abundance index (PAI) on the flight period Onset and Duration. $\triangle A I C$ is compared to the best-fitting model (bold). All models also contain the effect of transect identity. 


\begin{tabular}{|c|c|c|c|c|c|c|c|c|c|c|c|c|c|c|c|c|}
\hline \multirow{2}{*}{ Model } & \multicolumn{4}{|c|}{$\begin{array}{l}\text { E. sudetica Jeseník Mts } \\
2009-2020(\mathrm{~J})\end{array}$} & \multicolumn{4}{|c|}{$\begin{array}{l}\text { E. epiphron Jeseník Mts } \\
1995-1999+2009-2020 \\
\left(\mathrm{~J}_{\text {all }}\right)\end{array}$} & \multicolumn{4}{|c|}{$\begin{array}{l}\text { E. epiphron Jeseník Mts } \\
2009-2020\left(\mathrm{~J}_{\text {rec }}\right)\end{array}$} & \multicolumn{4}{|c|}{$\begin{array}{l}\text { E. epiphron Krkonoše Mts } \\
\text { 2010-2019 (K) }\end{array}$} \\
\hline & $\triangle A I C$ & Slope & SE & $d f$ & $\triangle A I C$ & Slope & SE & $d f$ & $\triangle A I C$ & Slope & SE & $d f$ & $\triangle A I C$ & Slope & SE & $d f$ \\
\hline Log(PAI) Transect & 10.6 & - & - & 33 & 15.2 & - & - & 38 & 13.1 & - & - & 33 & 0.0 & - & - & 36 \\
\hline $\begin{array}{l}\text { Log(PAI) Transect + } \\
\log (\text { Onset })\end{array}$ & 8.3 & -4.79 & 2.38 & 32 & 13.7 & -4.23 & 2.34 & 37 & 11.9 & -4.31 & 2.49 & 32 & 2.0 & 0.39 & 2.52 & 35 \\
\hline $\begin{array}{l}\log (\mathrm{PAI}) \sim \text { Transect }+ \\
\log (\text { Duration })\end{array}$ & 0.0 & 0.79 & 0.22 & 32 & 0.0 & 0.74 & 0.17 & 37 & 0.0 & 0.88 & 0.22 & 32 & 0.6 & -0.33 & 0.29 & 35 \\
\hline $\begin{array}{l}\log (\text { PAI }) \sim \text { Transect }+ \\
\log (\text { Onset })+ \\
\log (\text { Duration })\end{array}$ & 1.9 & - & - & 31 & 1.6 & - & - & 36 & 1.6 & - & - & 31 & 2.0 & - & - & 34 \\
\hline
\end{tabular}

2 


\section{Table 2 (on next page)}

Temporal trends in the population abundance index (PAI) and flight period Onset and Duration.

$\triangle A I C$ is compared to the best-fitting model (bold); separately for PAI, Onset, and Duration. 


\begin{tabular}{|c|c|c|c|c|c|c|c|c|c|c|c|c|c|c|c|c|}
\hline \multirow{2}{*}{ Model } & \multicolumn{4}{|c|}{$\begin{array}{c}\text { E. sudetica J } \\
2009-2020\end{array}$} & \multicolumn{4}{|c|}{$\begin{array}{c}\text { E. epiphron } J_{\text {all }} \\
1995-1999+2009-2020\end{array}$} & \multicolumn{4}{|c|}{$\begin{array}{l}\text { E. epiphron } \mathrm{J}_{\text {rec }} \\
2009-2020\end{array}$} & \multicolumn{4}{|c|}{$\begin{array}{l}\text { E. epiphron K } \\
2010-2019\end{array}$} \\
\hline & $\triangle A I C$ & Slope & SE & $d f$ & $\triangle A I C$ & Slope & SE & $d f$ & $\triangle A I C$ & Slope & SE & $d f$ & $\triangle A I C$ & Slope & SE & $d f$ \\
\hline \multicolumn{17}{|c|}{ Population abundance index (PAI) } \\
\hline $\begin{array}{l}\text { Log(PAI) } \\
\text { Transect }\end{array}$ & 3.0 & - & - & 33 & 0.0 & - & - & 38 & 0.0 & - & - & 33 & 8.1 & - & - & 36 \\
\hline $\begin{array}{l}\log (P A I) \sim \\
\text { Transect + Year }\end{array}$ & 0.0 & 0.060 & 0.028 & 32 & 0.3 & 0.020 & 0.017 & 37 & 0.2 & 0.039 & 0.031 & 32 & 0.0 & 0.115 & 0.036 & 35 \\
\hline \multicolumn{17}{|c|}{ Flight period onset } \\
\hline $\begin{array}{l}\text { Log(Onset) } \\
\text { Transect }\end{array}$ & 0.0 & - & - & 33 & 0.0 & - & - & 38 & 0.0 & - & - & 33 & 1.6 & - & - & 36 \\
\hline $\begin{array}{l}\text { Log(Onset) } \sim \\
\text { Transect + Year }\end{array}$ & 0.7 & -0.002 & 0.002 & 32 & 1.0 & -0.001 & 0.001 & 37 & 1.1 & 0.002 & 0.002 & 32 & 0.0 & -0.005 & 0.003 & 35 \\
\hline \multicolumn{17}{|c|}{ Flight period duration } \\
\hline $\begin{array}{l}\text { Log(Duration) } \\
\text { Transect }\end{array}$ & 0.3 & - & - & 33 & 11.0 & - & - & 38 & 0.0 & - & - & 33 & 0.0 & - & - & 36 \\
\hline $\begin{array}{l}\text { Log(Duration) } \\
\text { Transect + Year }\end{array}$ & 0.0 & 0.029 & 0.020 & 32 & 0.0 & 0.042 & 0.011 & 37 & 1.0 & 0.020 & 0.021 & 32 & 0.2 & 0.029 & 0.023 & 35 \\
\hline
\end{tabular}




\section{Table 3 (on next page)}

The effect of the climate predictors, each tested separately, on the population abundance index $(P A I)$.

The predictors were standardised to have zero mean and unit variance. The response variable (PAI) was log-transformed. $\triangle A I C=$ the difference of $A I C$ of each listed model containing a single climate variable, along with the effect of transect identity, compared to the corresponding null model without the effect of the climate variable; i.e. $\log (P A l) \sim$ Transect. Hence, models with lower $A I C$ compared to the null model have negative values of $\triangle A I C . \triangle A I C<-6$ was considered a strong (bold underlined) and $<-2$ a moderate (bold) indication of the respective predictor's effect. Empty cells (-): the predictor not available for the mountain range and time period. 


\begin{tabular}{|c|c|c|c|c|c|c|c|c|c|c|c|c|}
\hline \multirow[t]{2}{*}{ Model } & \multicolumn{3}{|c|}{$\begin{array}{l}\text { E. sudetica J } \\
2009-2020 \\
\text { (Null df = 33) }\end{array}$} & \multicolumn{3}{|c|}{$\begin{array}{c}\text { E. epiphron Jall } \\
1995-1997+2009-2020 \\
\text { (Null df }=38)\end{array}$} & \multicolumn{3}{|c|}{$\begin{array}{l}\text { E. epiphron } \mathrm{J}_{\text {rec }} \\
2009-2020 \\
(\text { Null df }=33)\end{array}$} & \multicolumn{3}{|c|}{$\begin{array}{l}\text { E. epiphron K } \\
2010-2019 \\
(\text { Null df = 36) }\end{array}$} \\
\hline & $\Delta A I C$ & Slope & SE & $\Delta A I C$ & Slope & SE & $\Delta A I C$ & Slope & SE & $\triangle A I C$ & Slope & SE \\
\hline Null model & 0.0 & & & 0.0 & & & 0.0 & & & 0.0 & & \\
\hline$P_{\text {tot }}$ Aut & 1.99 & 0.01 & 0.10 & 1.61 & -0.06 & 0.10 & 1.69 & -0.06 & 0.11 & -1.90 & 0.22 & 1.89 \\
\hline$T_{\text {avg }} A u t$ & 1.59 & 0.06 & 0.10 & 1.59 & 0.06 & 0.25 & 1.22 & 0.09 & 0.11 & -1.37 & 0.34 & 0.19 \\
\hline$T_{\max } A u t$ & 0.91 & -0.10 & 0.10 & 1.67 & -0.06 & 0.10 & 1.64 & -0.06 & 0.11 & 1.86 & 0.05 & 0.13 \\
\hline$T_{\min } A u t$ & -3.12 & 0.21 & 0.10 & -5.70 & 0.26 & 0.09 & $\underline{-9.08}$ & $\underline{0.33}$ & $\underline{0.10}$ & $\underline{-6.23}$ & $\underline{0.55}$ & $\underline{0.20}$ \\
\hline$T_{\text {ground } A u t}$ & -5.77 & 0.26 & 0.09 & - & - & - & $\underline{-11.08}$ & $\underline{0.35}$ & $\underline{0.09}$ & - & - & - \\
\hline$P_{\text {tot }}$ Win & $\underline{-6.99}$ & $\underline{0.28}$ & $\underline{0.09}$ & $\underline{-11.25}$ & $\underline{0.33}$ & $\underline{0.09}$ & $\underline{-10.14}$ & $\underline{0.34}$ & $\underline{0.09}$ & $\underline{-7.80}$ & $\underline{0.65}$ & $\underline{0.21}$ \\
\hline$T_{\text {avg }}$ Win & 1.33 & -0.08 & 0.10 & -4.61 & -0.25 & 0.10 & $\underline{-6.01}$ & $\underline{-0.28}$ & $\underline{0.10}$ & 1.91 & -0.06 & 0.20 \\
\hline$T_{\max } W i n$ & -1.42 & 0.18 & 0.10 & 1.89 & 0.03 & 0.10 & 1.62 & 0.07 & 0.11 & 1.74 & 0.10 & 0.20 \\
\hline$T_{\min } W i n$ & 1.47 & -0.07 & 0.10 & -1.97 & -0.19 & 0.10 & -3.13 & -0.23 & 0.10 & 1.79 & 0.08 & 0.18 \\
\hline$T_{\text {ground }} W i n$ & 1.12 & -0.09 & 0.10 & - & - & - & -4.01 & -0.25 & 0.10 & - & - & - \\
\hline Snow $_{\text {days }}$ & 1.75 & 0.05 & 0.10 & - & - & - & -1.47 & 0.19 & 0.11 & - & - & - \\
\hline$P_{t o t} \mathrm{Spr}$ & -5.74 & -0.26 & 0.09 & -1.74 & -0.18 & 0.10 & -1.68 & -0.20 & 0.11 & -1.78 & -0.22 & 0.12 \\
\hline$T_{\text {avg }} S p r$ & $\underline{-7.30}$ & $\underline{0.28}$ & $\underline{0.09}$ & -14.01 & $\underline{0.36}$ & $\underline{0.09}$ & $\underline{-22.55}$ & $\underline{0.45}$ & $\underline{0.08}$ & -4.01 & 0.67 & 0.28 \\
\hline$T_{\max } \mathrm{Spr}$ & -5.91 & 0.26 & 0.09 & -3.52 & 0.22 & 0.10 & -4.65 & 0.26 & 0.10 & 1.97 & 0.04 & 0.23 \\
\hline$T_{\min } \mathrm{Spr}$ & -3.58 & 0.22 & 0.10 & -2.45 & 0.20 & 0.10 & -3.96 & 0.25 & 0.10 & 1.58 & -0.14 & 0.23 \\
\hline$T_{\text {ground }} \mathrm{Spr}$ & 0.09 & 0.13 & 0.10 & - & - & - & 0.38 & 0.13 & 0.11 & - & - & - \\
\hline$P_{\text {tot }}$ Sum & 0.93 & -0.10 & 0.10 & 2.00 & 0.00 & 0.10 & 2 & 0.00 & 0.11 & -5.19 & -0.29 & 0.11 \\
\hline$T_{\text {avg }}$ Sum & -0.50 & 0.15 & 0.10 & 1.63 & 0.06 & 0.11 & 1.14 & 0.10 & 0.11 & 0.90 & 0.26 & 0.26 \\
\hline$T_{\max }$ Sum & 1.85 & -0.04 & 0.10 & 1.89 & 0.03 & 0.11 & 1.67 & 0.06 & 0.11 & -0.40 & 0.24 & 0.16 \\
\hline$T_{\min } \mathrm{Sum}$ & -5.21 & -0.25 & 0.09 & -1.89 & -0.19 & 0.10 & -2.7 & -0.22 & 0.11 & 1.89 & 0.10 & 0.32 \\
\hline$T_{\text {ground }} S u m$ & -0.93 & -0.16 & 0.10 & - & - & - & -3.32 & -0.24 & 0.10 & - & - & - \\
\hline
\end{tabular}

